\title{
生活習慣病・メタボリックシンドロームの予防・ 生活習慣改善のための年代別・性別基準範囲
}

小川 哲平 ${ }^{1)}$ 菅野 剛史 ${ }^{2)}$

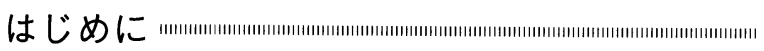

健診・人間ドックの臨床検查值を評価し，生活習 慣改善, 二次検診指示, 治療などの判断には, 健康 度や異常度をはかる尺度が必要となる。従来は「正 常值」がこの尺度として用いられていた。正常值は, 健常と思われる人の集団(多くは成人の健診受診者) を対象として検査を行い, 平均値 $\pm 2 \times$ 標準偏差 （2SP）を正常値としてきた。その結果, 健康と思わ れる約 $5 \%$ が正常值から外れること，正常人の定義 がはっきり定義されていない，また正常值が，健常 と病気を区分する識別値と䛊解されることなどの問 題があった。さらに充分な統計学的な信頼性を満た す $\mathrm{n}$ 数（母集団数）についても明確な定義がなされ ていなかった。

\section{検査の精度管理，標準化と}

基準範囲・基準值

Dybkar ら（1973 年）により, 正常值の不適切さが 指摘され，基準値 reference values を提案された。 基準値を算出する基本と母集団の条件を定め，その 母集団の同じ条件の受診者が自分の検査值をその母 集団と比較 referするという概念である。この考え 方が国際臨床化学連合 International Federation of Clinical Chemistry, IFCC（1979 年）に取り入れられ た。しかし当時の臨床検査の精度管理と標準化の状 況から，分析值の施設間格差が大きな障害としてあ り, 年代別・性別などの基本個体の蒐集は不可能で あり，成人の基本個体による基準範囲に止まらざる を得なかった。

米国臨床検查標準委員会 National Committee for Clinical Laboratory Standards, NCCLS（1992 年）に

1）慶友会城東病院

2 ）浜松市医療公社
基準範囲 reference intervals が標準法（認証標準） として採用された ${ }^{1) 。}$

我が国においても日本臨床検査医学会 (平成 14 年）により基準值，基準範囲についての提言され， 臨床検查の判定基準が定まった ${ }^{2 \sim 4)}$ 。

基準範囲を求めるための対象者を, 薬物摂取や潜 在性疾患など検査值に影響を及ほす可能性のある因 子を除外し，年代別・性別について集めることは， 一施設のみでは不可能で, 多施設共同作業が必要と なる。近年の臨床検查分析技術の著しい向上によ り, 臨床検査の精度管理と標準化が発展し, 施設間 の格差が解消し，多施設共同による大規模調査によ り母集団の設定を大きくすることがようやく可能と なった。

\section{基準範囲の定義}

基準範囲とは, 健常者であり, 生活習慣を同じく する基準個体からなる母集団の分布で, 中央值を含 む $95 \%$ の個体が占める下限值と, 上限值の範囲と定 義される。

従来は, 年齢別の基準個体 $\mathrm{n} 120$ 以上の集計は, 非 常に大きな集団となるため, やむを得ず，性差のな い成人検查值による基準範囲が用いられてきた。当 然のことながら, 臨床検査值は, 性差が存在し, ま た各年代にはそれぞれ共通する様々な環境変化の影 響を受けた結果や加齢そのものによる変化がみられ る。したがって，年代別・性別基準範囲がようやく 設定されるようになったことは極めて意義あること と思われる。

\section{基準範囲と診療ガイドライン(病態識別値) ․!!!}

生命予後に密接に関係する血圧, 血糖値, 脂質代 謝検査值などに関して, 自立した長命が可能な理想 
生活習慣病・メタボリックシンドロームの予防・生活習慣改善のための年代別・性別基準範囲

表 1 基準範囲と診療ガイドラインの対応

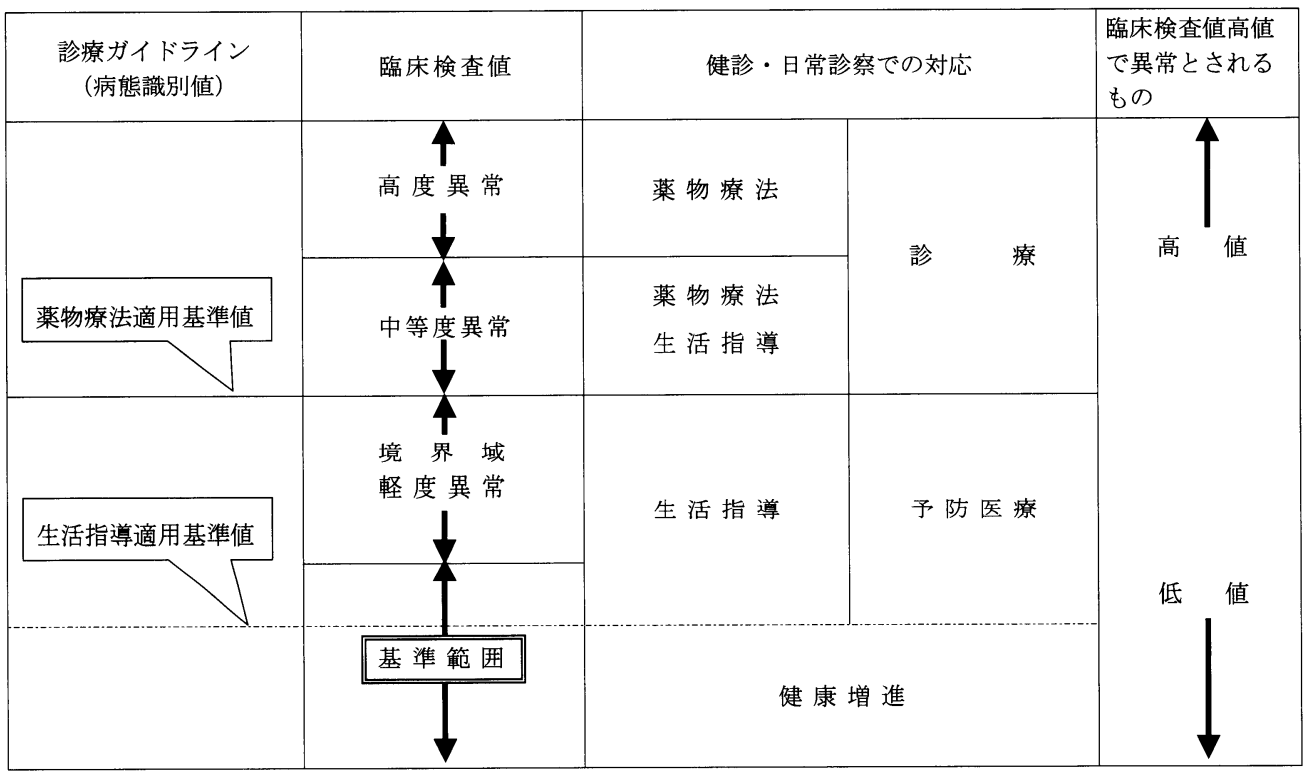

的な検査值として，管理基準ないし管理目標値が定 められている。これらには, (1)生活指導 (食事療法, 運動療法）の適用基準值，2薬物療法適用基準值，

(3)治療目標值が定められている。

健診受診者に，基準範囲とこれらの管理目標値を いかに理解されるように説明することが極めて重要 である（表 1）。

年代別・性別により設定された基準範囲により， 受診者へのより細やかな健康指導が行われる ${ }^{5,6)}$ 。

さらに，これからの健診には, 個人の継続的な健 診成績の蓄積によって設定された「個人の基準値」 によって, その変動をみることの重要性が求められ $\tau く る 。$

日本総合健診医学会第 32 回大会において, 大会長 シンポジウム「基準範囲」を, 司会：小川哲平，菅 野剛史によって，大櫛陽一，柴田健雄の参加によっ て行われた。

日本総合健診医学会優良認定施設 44 施設の参加 により，75万人を超える健診受診者成績を提供され た。これらの施設はいずれも, 日本総合健診医学会 精度管理のほかに, 日本医師会臨床検査精度管理, 日臨技臨床検査精度管理, 全衛連臨床検査精度管理 などの複数の精度管理を受けいずれも合格してい る。これらの大きな母集団を，大櫛，柴田によって 開発されたプログラムにより統計処理された ${ }^{7) 。}$

作成された年代別・性別基準值はその後同様に, 菅野, 田内らにより別に行われた地域の基準範囲 と，ほとんど同様であった ${ }^{8)}$ 。
このことは，本邦において臨床化学の標準化，精 度管理が共有化できることを実証した点でも大きな 意義を持ち，臨床化学の成果を物語っている。

年代別，性別の基準範囲を，(1)検査よりみる基準 範囲表と，(2)各年代別よりみる基準範囲表を示しま したので，健診面接の場で御活用下されば幸いで †。

本研究の一部は, 平成 18 年度 (財) 慶應健康相談セ ンター研究費助成金による。

\section{【共同研究者】}

I ）基準範囲設定のプログラム開発と統計処理 大櫛陽一, 柴田健雄 （東海大学医学部）

II ）基準個体の選出

相澤 紘 （(医)社団潤康会芝パーククリニック） 飯沼雅朗 （蒲郡市総合保健センター人間ドック） 石井敏之（(医)社団藤順会藤沢総合健診セン 夕一)

今西晃郎 ((医)社団アルコ会アルコクリニッ ク総合健診センター)

植田理彦（(医)社団六医会内幸町診療所）

上村博幸 （(社)岐阜県労働基準協会連合会労 働衛生センター)

内原正勝（武蔵野十字病院健診センター）

馬杉則彦（労働福祉事業団海外勤務健康管理 センター)

江原良貴 （(財)江原積善会 ES クリニック） 
大道重夫 ((財) 嵫賀保健研究センター)

加藤哲郎 ((財) 秋田県総合保健事業団秋田県 総合保健センター)

金城幸善 （(財)沖縄県総合保健協会）

菅野千秋（(株)日立製作所水戸総合病院総合 健診センター)

菊池順一郎 （(財)ヘルスサイエンスセンター） 木下勝也 ((財)近畿健康管理センター三重事 業部診療所)

木村篤人（(医)財団立川中央病院附属健康ク リニック)

蔵田孝雄 （(医) 親愛天神クリニック）

小林武彦 ((医)愛生館小林記念病院健康管理 センター)

小林 毅 (社会保険北海道健康管理センター)

近藤慶二 （(財)高知県総合保健協会 $)$

清水孝郎 ((財)住友病院健康管理センター)

高築勝義 （医療法人社団こころとからだの元 氣プラザ)

高松慶太（特定医療法人財団慈生会野村病院 予防医学センター)

竹原靖明 ((医)社団相和会横浜総合健診セン 夕ー)

関 捨男 ((財) 福井県予防医学協会)

田中 誠（(財)西日本産業衛生会北九州産業 衛生診療所)

塚本 昇 ((医)生長会ベルクリニック)

中上和義 ((財)近畿健康管理センター大阪事 業部診療所)

萎沢利行 （藤間病院総合健診システム）

林 幸三（広島簡易保険総合健診センター）

日野 孝 ((財)日本予防医学会関西支部附属 診療所)

廣瀬光彦 （(医)オリエンタルクリニック）

福田崇典 ((財) 芙蓉協会聖隷沼津第一クリ ニック聖隷沼津健康診断センター)

藤田正憲 （(財)近畿健康管理センター滋賀事 業部診療所)
藤田葉子（(医)いちえ会伊月健診クリニック）

船津和夫（(財)三越厚生事業団三越総合健診 センター)

松岡謙二（(財)関西労働保健協会附属アク ティ健診センター)

松崎秀幸 （高野病院総合健診センター）

宮永 實 ((財)関西労働保健協会附属千里 LC 健診センター)

村岡英夫 ((財) 福島県保健衛生協会成人病七 ンター診療所)

永井秀明 （(財)ちば県民保健予防財団附属予 防医療クリニック)

山口佳晴 （サン虎の門クリニック）

山瀧 一 ( (財) 君津健康センター)

和田高士（東京慈恵会医科大学健康医学セン ター)

文＼cjkstart献

1) Sasse EA, Doumas BD, Miller WG, et al. : How to Define and Determine Reference Intervals in the Clinical Laboratory ; Approved Guideline-Second edition, NCCLS, 2000

2) 河合忠 : 基準值と境界值とカットオフ值, 1-5, 基準值と 異常值の間一その判定と対策一, 河合忠編, 中外医学社, 2006

3）菅野剛史 : 基準範囲をめぐる諸問題, 臨床病理 $44: 241$ 244, 1996

4）高木康 : 基準範囲の考え方, 36-40, 最新臨床検查の $\mathrm{ABC}$, 日本医師会雑誌 135 (特別号 2), 橋本信也編, 2006

5）田村政紀 : 加齢による基準值の変動, モダンメディア 48 (12) : 317-332, 2002

6) 大櫛陽一, 柴田健雄, 菅野剛史ほか: 日本人 70 万人の データからみる性差と年齢依存, 86-99, 性差医療一性差 研究が医療を変える, 天野恵子編, 真興交易, 2006

7）柴田健雄, 大櫛陽一, 小川哲平ほか: 基準範囲設定のため の国際標準NCCLS 法互換の新しい方法を含むプログラ ムの開発および妥当性の検証, 総合健診 $31: 648-655$, 2004

8) Kanno T, Tauchi K, Ohgushi Y, et al. : Estimation of Reference Intervals for the Shizuoka Prefecture of Japan and Comparison with those Obtained from Other Two Large-scale Studies of Reference Populations in Japan, HEP 33 : 463-466, 2006 
年代別・性別基準範囲一覧表

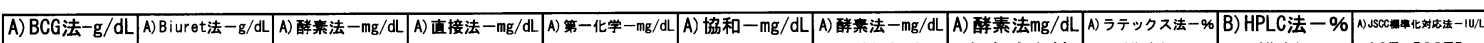
\begin{tabular}{l|c|c|c|c|}
$H D L-C$ & $H D L-C$ & 中性脂肪 & 空腹時血糖 & HbAlC \\
\hline
\end{tabular} HbA10

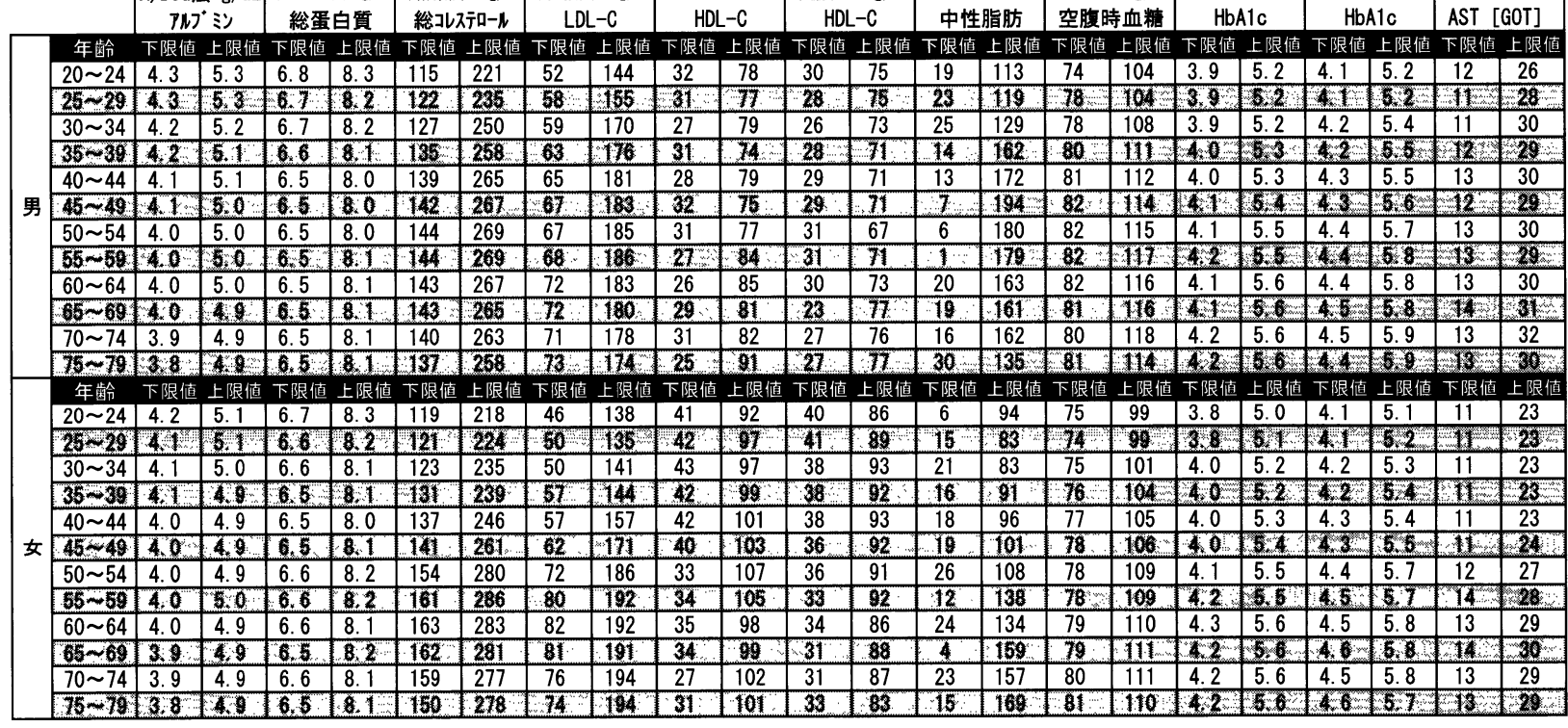

\begin{tabular}{|c|c|c|c|c|c|c|c|c|c|c|c|c|c|c|c|c|c|c|c|c|c|c|c|}
\hline & \multicolumn{2}{|c|}{ 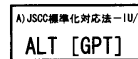 } & \multicolumn{2}{|c|}{ 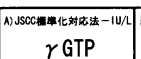 } & \multicolumn{2}{|c|}{$\begin{array}{l}\text { isz法-IU/L } \\
\gamma \text { GTP }\end{array}$} & \multicolumn{2}{|c|}{ 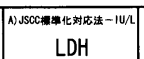 } & \multicolumn{2}{|c|}{$\begin{array}{c}\text { B) GSCC法-IU/L } \\
\text { LDH }\end{array}$} & \multicolumn{2}{|c|}{ 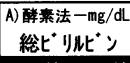 } & \multicolumn{2}{|c|}{ 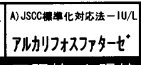 } & \multirow{2}{*}{\multicolumn{2}{|c|}{ 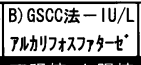 }} & \multicolumn{2}{|c|}{ 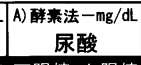 } & \multirow{2}{*}{\multicolumn{2}{|c|}{ 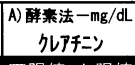 }} & \multicolumn{2}{|c|}{$\begin{array}{c}\text { B) Jaffe法-mg/dL } \\
\text { クルテニン }\end{array}$} \\
\hline & & & & & & & & & & & & 下限値 & 限値 & 下限值 & 上限值 & F限值 & & & & & & & \\
\hline & & 6 & 26 & & 32 & & 7 & & & ( & & & & & 312 & & & & & & & & \\
\hline & $25 \sim 29$ & 6 & 2 & & 36 & & 20 & & 206 & 25 & & & & & 293 & & & & & & & & \\
\hline & $30 \sim 34$ & 5 & 34 & & 11 & & & 13 & 206 & 203 & & & & & 294 & & 199 & & & & 1 & & \\
\hline & $35-39$ & 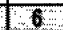 & $\sqrt{3}$ & & 4 & & & & & & & & & & 20 & & 100 & & & & & & \\
\hline & $\begin{array}{l}40 \sim 44 \\
\end{array}$ & 4 & 38 & & 53 & & 39 & 115 & 208 & 204 & 410 & & & & 285 & 77 & 192 & & 5 & & .1 & 0.7 & \\
\hline & & & 34 & & 54 & & 37 & 117 & & 203 & & & & & 287 & & 189 & & & & 9 & 7 & \\
\hline & $50 \sim 54$ & & 3 & & 57 & & 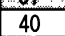 & 1 & 213 & 203 & & & 1.2 & & 289 & & 192 & & 6.4 & & & .7 & \\
\hline & \begin{tabular}{|c|}
$55 \sim 59$ \\
\end{tabular} & 8 & $\frac{3}{3}$ & 8 & 51 & & 38 & 121 & 216 & 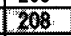 & & & 1.2 & & 298 & & 195 & 16 & 3 & 6 & 10 & 7 & \\
\hline & $\begin{array}{l}60 \sim 64 \\
\end{array}$ & 7 & 3 & 8 & 49 & & 40 & 123 & 218 & 216 & & & 1.2 & & 300 & 79 & 194 & & & 5 & 1.1 & & \\
\hline & $65 \sim 69$ & 8 & $\sqrt{3}$ & 8 & 48 & & & 22 & 226 & 6 & & & $\overline{1.3}$ & & 306 & 78 & 199 & & 3 & & 142 & & \\
\hline & $70 \sim 74$ & 3 & 32 & 8 & 45 & & 32 & 132 & 222 & 19 & & & 1.2 & 12 & 297 & 70 & 205 & & & 6 & 1.2 & & \\
\hline & $\sim 70$ & 8 & 25 & 10 & 39 & & 31 & 129 & 239 & $2<9$ & 400 & & 2 & 12 & 317 & 74. & ve & & 6 & 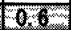 & 2 & & \\
\hline & & & & & & & & & & & & & & & 上限値 & & 上限値 & 値 & 上限値 & 限値 & 上限値 & 艮値 & \\
\hline & & & 17 & 9 & 21 & & $\sqrt{12}$ & 106 & & & & & & $\infty$ & 242 & 7 & 17 & & & & & & \\
\hline & $25 \sim 29$ & 6 & 18 & 8 & 21 & & & & 38 & & & & & & & & & $a t$ & & & 8 & 6 & \\
\hline & & 6 & 18 & 7 & 21 & & & & & & & & & & 22 & & & & & & & 14 & \\
\hline & 3 & 6 & 20 & & 22 & 7 & & 110 & & 98 & & & T. & 86 & 2 & & & 9 & & & & 5 & \\
\hline & & & & & 2 & & & & & & & & & & & & & & & & 0.8 & 5 & \\
\hline & & 7 & 2 & 1 & 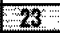 & & & & & & & & & & & & & & & & & 5 & \\
\hline & & & 24 & 0 & 25 & 5 & 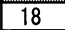 & $\sqrt{12}$ & 225 & 22 & & & 1. & 78 & 32 & 6 & 20 & & & & 8 & 5 & \\
\hline & & 8 & 2 & 8 & 28 & 5 & $1 \pi$ & & & & & & & & 13 & & 21 & 12 & & & $a$ & 2 & \\
\hline & & 8 & 2 & & 2 & & $\Omega$ & & 23 & & & & & & & & 2 & & & & & & \\
\hline & & 8 & 20 & 8 & 2 & 5 & 11 & 14 & 23 & 2 & 48 & 10.3 & 1.0 & 119 & $\sqrt{34}$ & 88 & 22 & 2,8 & {$[6$} & 4 & 8 & 5 & \\
\hline & & & 25 & 9 & 28 & 6 & 18 & 14 & & 2 & $4 !$ & & & & & 9 & 2 & & & & & 0. & \\
\hline & & 4 & 22 & $y$ & 27 & 5 & 18 & 133 & 1.200 & 245 & 504 & & & 179 & 301 & & & & & 104 & 10.9 & 0.5 & \\
\hline
\end{tabular}

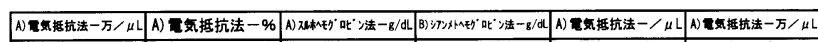

\begin{tabular}{|c|c|c|c|c|c|c|c|c|c|c|c|c|c|c|c|c|c|c|}
\hline $20 \sim 24$ & 441 & 563 & 41.0 & 50.5 & 13.8 & 17.2 & 13.7 & 16.9 & 3264 & 8550 & 14.3 & 33.3 & 96 & 145 & 51 & 85 & 100 & 257 \\
\hline
\end{tabular} \begin{tabular}{|l|l|l|l|l|l|l|l|l|l|l|l|l|l|l|l|l|l|l|l|}
\hline $25 \sim 29$ & 438 & 559 & 40.8 & 50.6 & 13.8 & 17.0 & 13.7 & 16.9 & 3285 & 8463 & 14.0 & 34.3 & 94 & 145 & 53 & 87 & 16.0 & 25.7 \\
\hline
\end{tabular} \begin{tabular}{l|l|l|l|l|l|l|l|l|l|l|l|l|l|l|l|l|l|l}
\hline $30 \sim 34$ & 432 & 560 & 40.4 & 50.4 & 13.7 & 17.0 & 13.6 & 17.0 & 3192 & 7921 & 15.0 & 32.3 & 93 & 145 & 53 & 89 & 16.9 & 28.5 \\
\hline
\end{tabular} \begin{tabular}{|l|lll|l|l|l|l|l|l|l|l|l|l|l|l|l|l|l|}
\hline $35 \sim 39$ & 426 & 554 & 40.0 & 50.4 & 13.6 & 17.0 & 13.5 & 16.9 & 3127 & 7936 & 14.9 & 31.6 & 92 & 144 & 54 & 92 & 17.7 & 28.6 \\
\hline
\end{tabular}

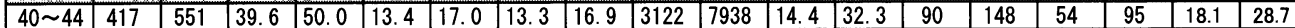

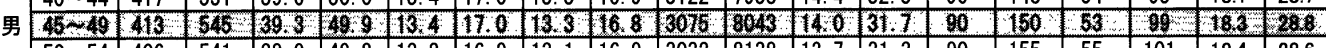

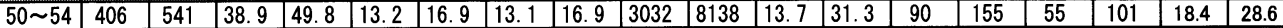

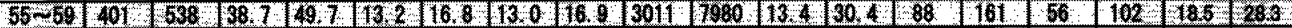
\begin{tabular}{|l|l|l|l|l|l|l|l|l|l|l|l|l|l|l|l|l|l|l}
\hline $60 \sim 64$ & 395 & 536 & 38.3 & 49.6 & 13.0 & 16.8 & 12.9 & 16.7 & 3134 & 7797 & 12.7 & 29.8 & 92 & 164 & 57 & 101 & 18.6 & 28.2 \\
\hline
\end{tabular} \begin{tabular}{|l|l|l|l|l|l|l|l|l|l|l|l|l|l|l|l|l|l|l|l|l|}
\hline $65 \sim 69.8$ & 388 & 536 & 37.8 & 49.6 & 12.8 & 16.8 & 12.7 & 16.6 & 3095 & 7862 & 12.2 & 29.0 & 98 & 165 & 58 & 100 & 18.5 & 28.5 \\
\hline
\end{tabular} \begin{tabular}{l|l|l|l|l|l|l|l|l|l|l|l|l|l|l|l|l|l|l}
$70 \sim 74$ & 382 & 534 & 37.4 & 49.6 & 12.7 & 16.7 & 12.4 & 16.7 & 3009 & 8153 & 11.6 & 28.4 & 99 & 168 & 57 & 99 & 18.0 & 28.3 \\
\hline
\end{tabular}

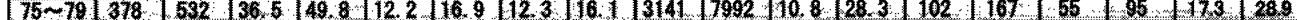

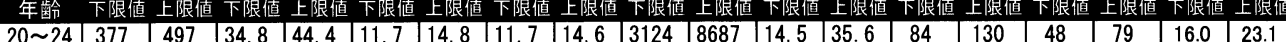
\begin{tabular}{|l|l|l|l|l|l|l|l|l|l|l|l|l|l|l|l|l|l|l|}
\hline $20 \sim 24$ & 377 & 497 & 34.8 & 44.4 & 11.7 & 14.8 & 11.7 & 14.6 & 3124 & 8687 & 14.5 & 35.6 & 84 & 130 & 48 & 79 & 16.0 & 23.1 \\
\hline $25 \sim 29$ & 372 & 495 & 34.9 & 44.1 & 11.6 & 14.8 & 11.6 & 14.5 & 2580 & 8453 & 15.0 & 33.6 & 82 & 129 & 48 & 80 & 16.1 & 22.8 \\
\hline
\end{tabular}

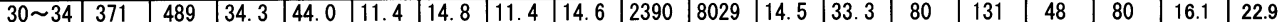
\begin{tabular}{|l|l|l|l|l|l|l|l|l|l|l|l|l|l|l|l|l|l|l|l|}
\hline $35 \sim 39$ & 368 & 487 & 33.9 & 44.0 & 11.5 & 14.8 & 11.4 & 14.7 & 2808 & 7063 & 14.5 & 32.9 & 78.734 & 49 & 82 & 16.1 & 23.7 \\
\hline
\end{tabular}

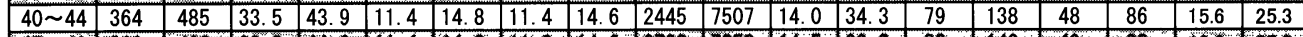

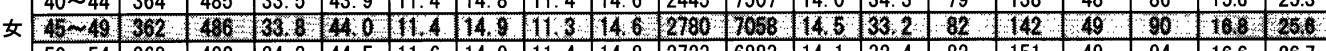

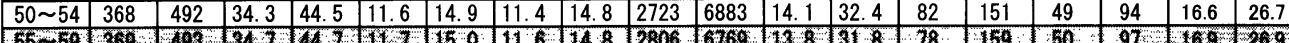
\begin{tabular}{|l|l|l|l|l|l|l|l|l|l|l|l|l|l|l|l|l|l|l|l|l|}
\hline $55 \sim 59$ & 369 & 493 & 34.7 & 44.7 & 11.7 & 15.0 & 11.6 & 14.8 & 2806 & 6769 & 13.8 & 31.8 & 78 & 159 & 50 & 97 & 16.9 & 26.9 \\
\hline
\end{tabular} \begin{tabular}{llllllllllllllllllllll}
$60 \sim 64$ & 365 & 494 & 34.6 & 44.7 & 11.6 & 15.0 & 11.5 & 14.8 & 2803 & 7075 & 13.5 & 31.6 & 88 & 159 & 52 & 97 & 16.9 & 27.7 \\
\hline
\end{tabular} \begin{tabular}{|l|l|l|l|l|l|l|l|l|l|l|l|l|l|l|l|l|l|l|}
\hline $65 \sim 69$ & 363 & 493 & 34.3 & 45.0 & 11.5 & 15.1 & 11.6 & 14.8 & 2914 & 7154 & 13.3 & 31.0 & 91 & 164 & 54 & 97 & 17.3 & 27.2 \\
\hline $70 \sim 74$ & 360 & 501 & 34.5 & 45.6 & 11.5 & 15.2 & 11.2 & 14.9 & 2878 & 7679 & 13.3 & 30.5 & 97 & 165 & 54 & 96 & 16.9 & 29.5 \\
\hline
\end{tabular} \begin{tabular}{|l|l|l|l|l|l|l|l|l|l|l|l|l|l|l|l|l|l|l|}
\hline $75 \sim 79$ & 356 & 494 & 33.9 & 45.8 & 11.3 & 15.1 & 11.2 & 14.9 & 2403 & 8239 & 12.4 & 30.6 & 100 & 166 & 55 & 95 & 17.1 & 29.7 \\
\hline
\end{tabular} 

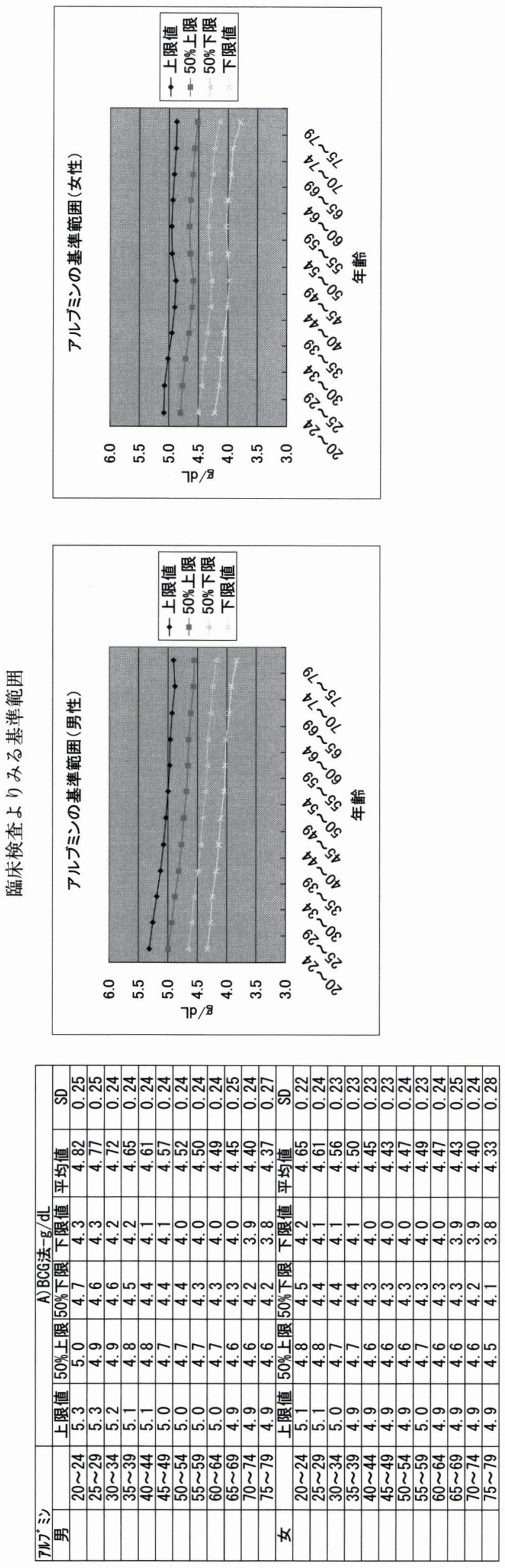
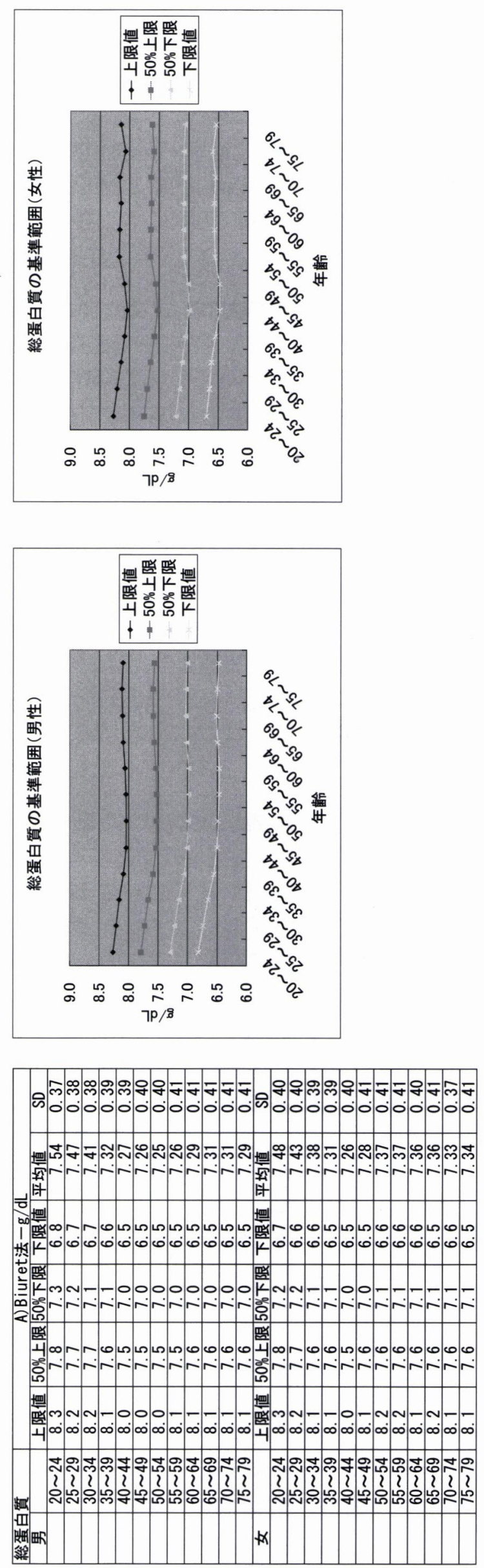

HEP Vol. 34, No. 5, 2007 

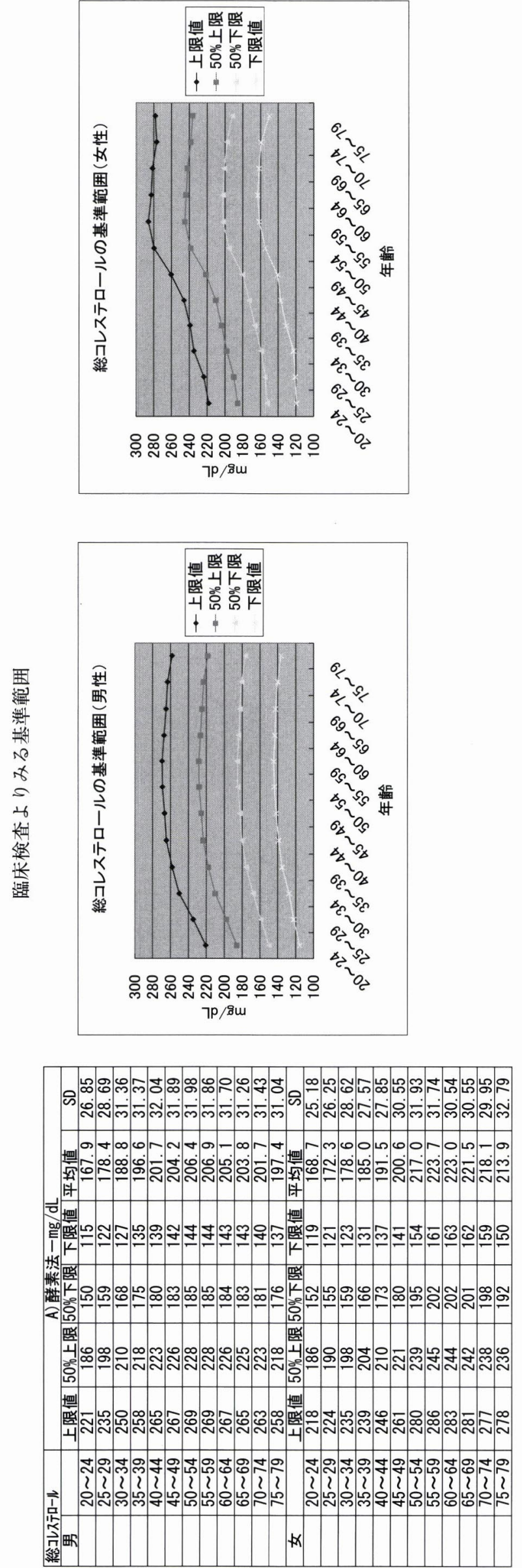
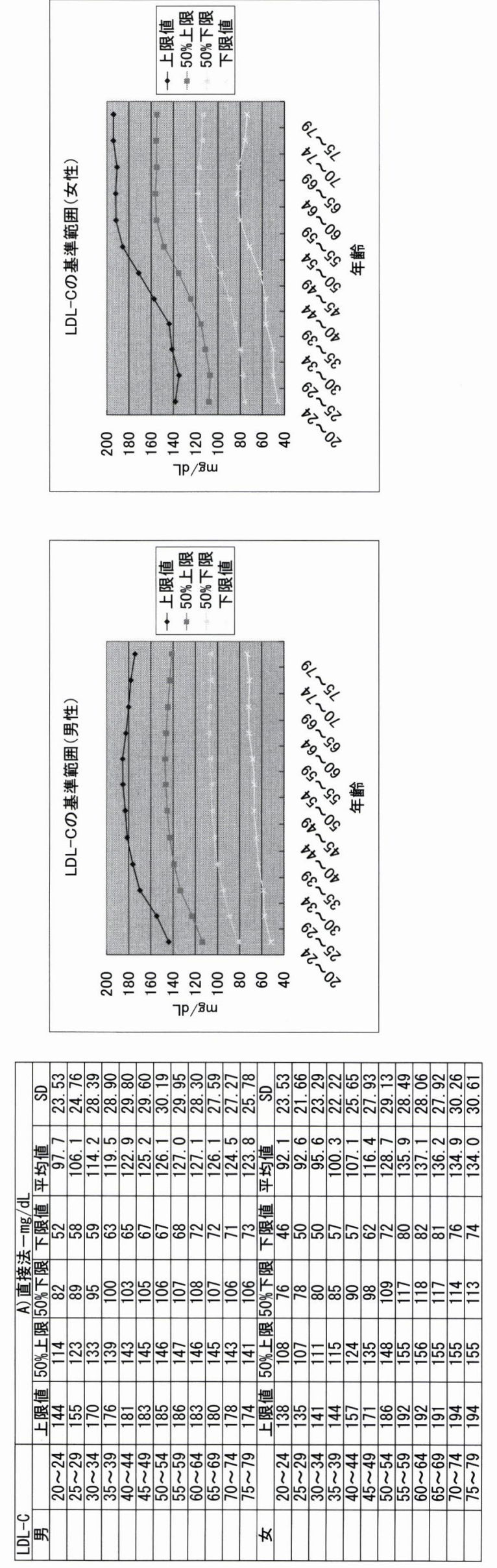

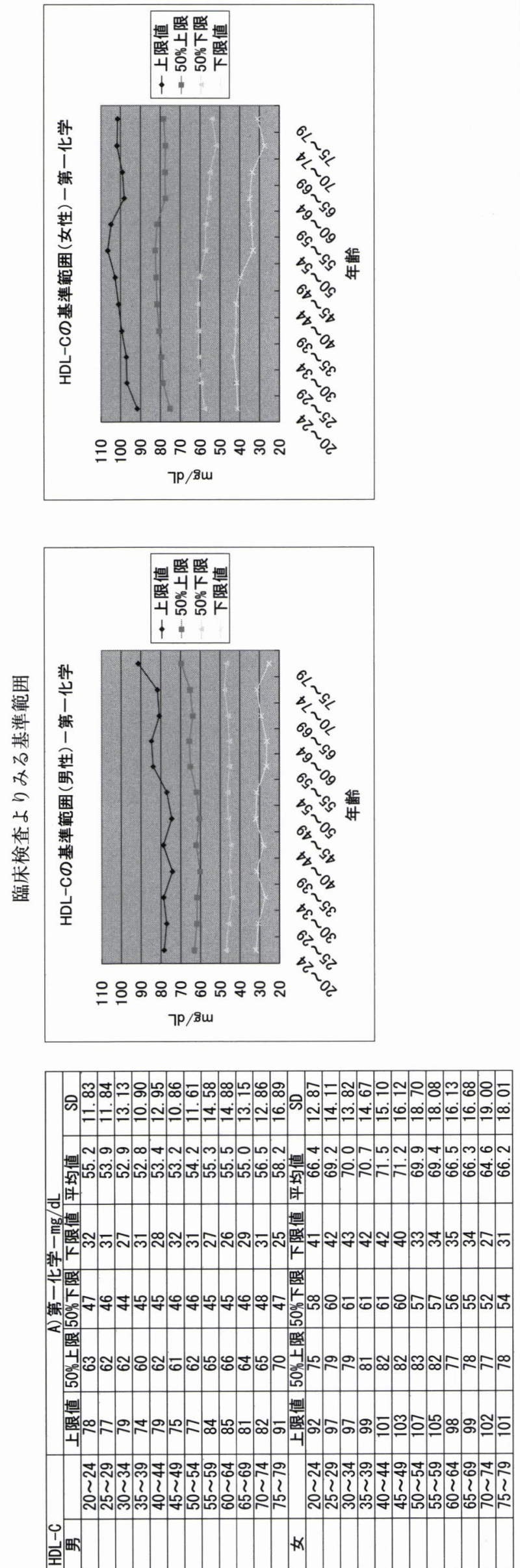
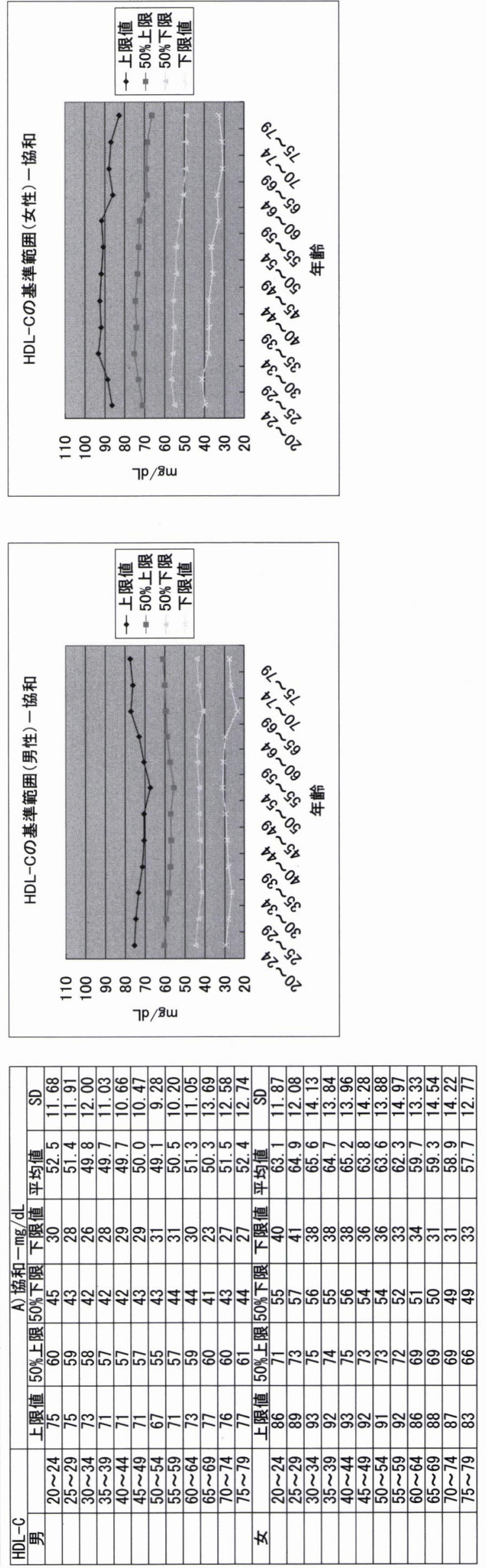

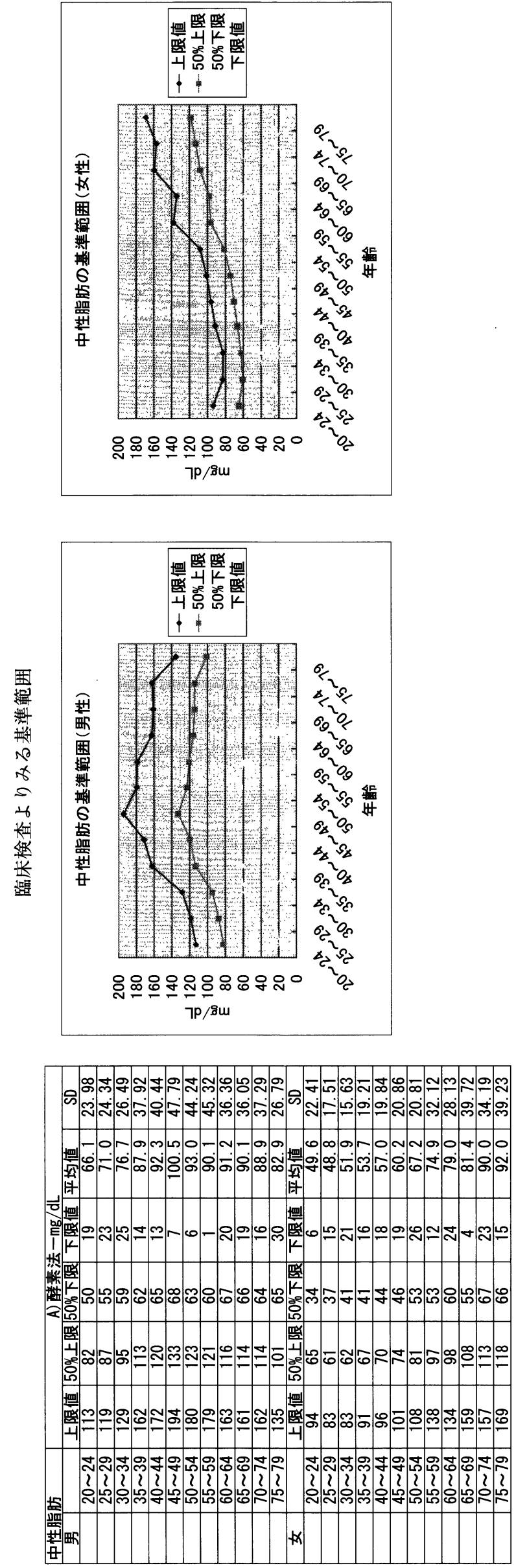
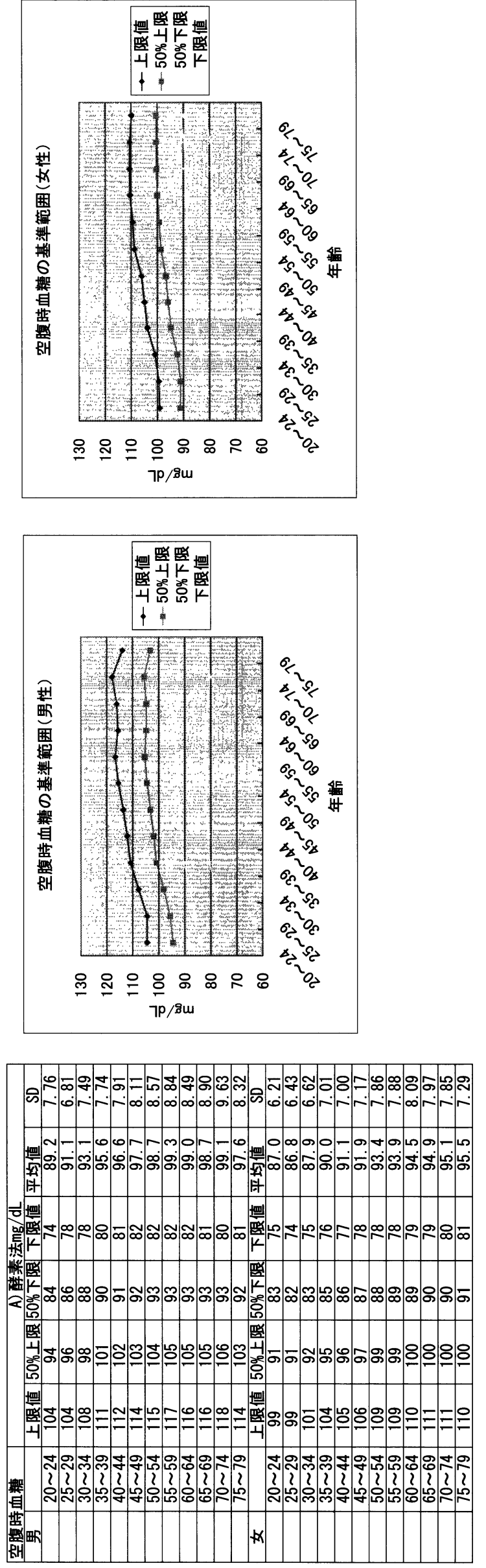

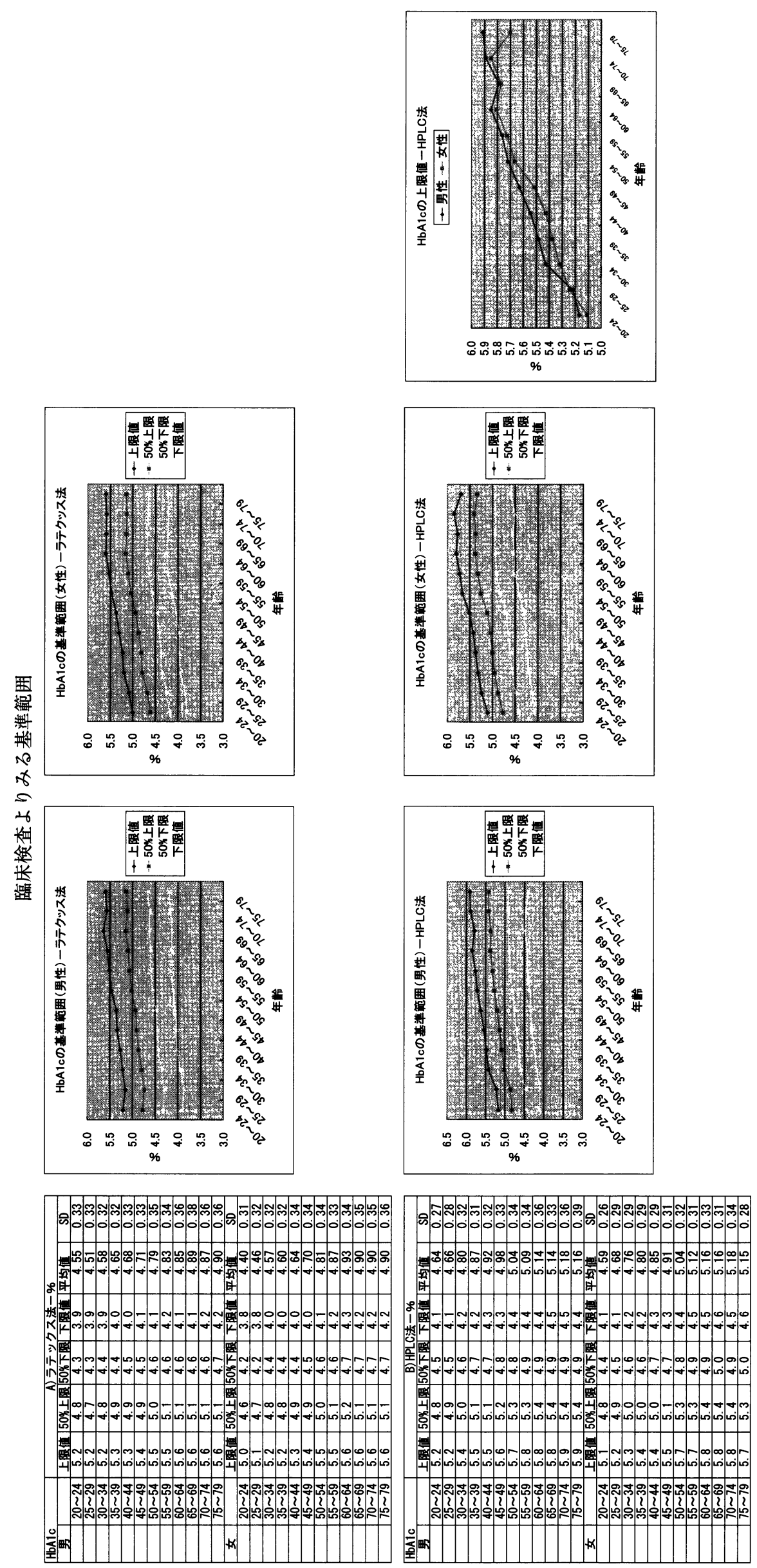

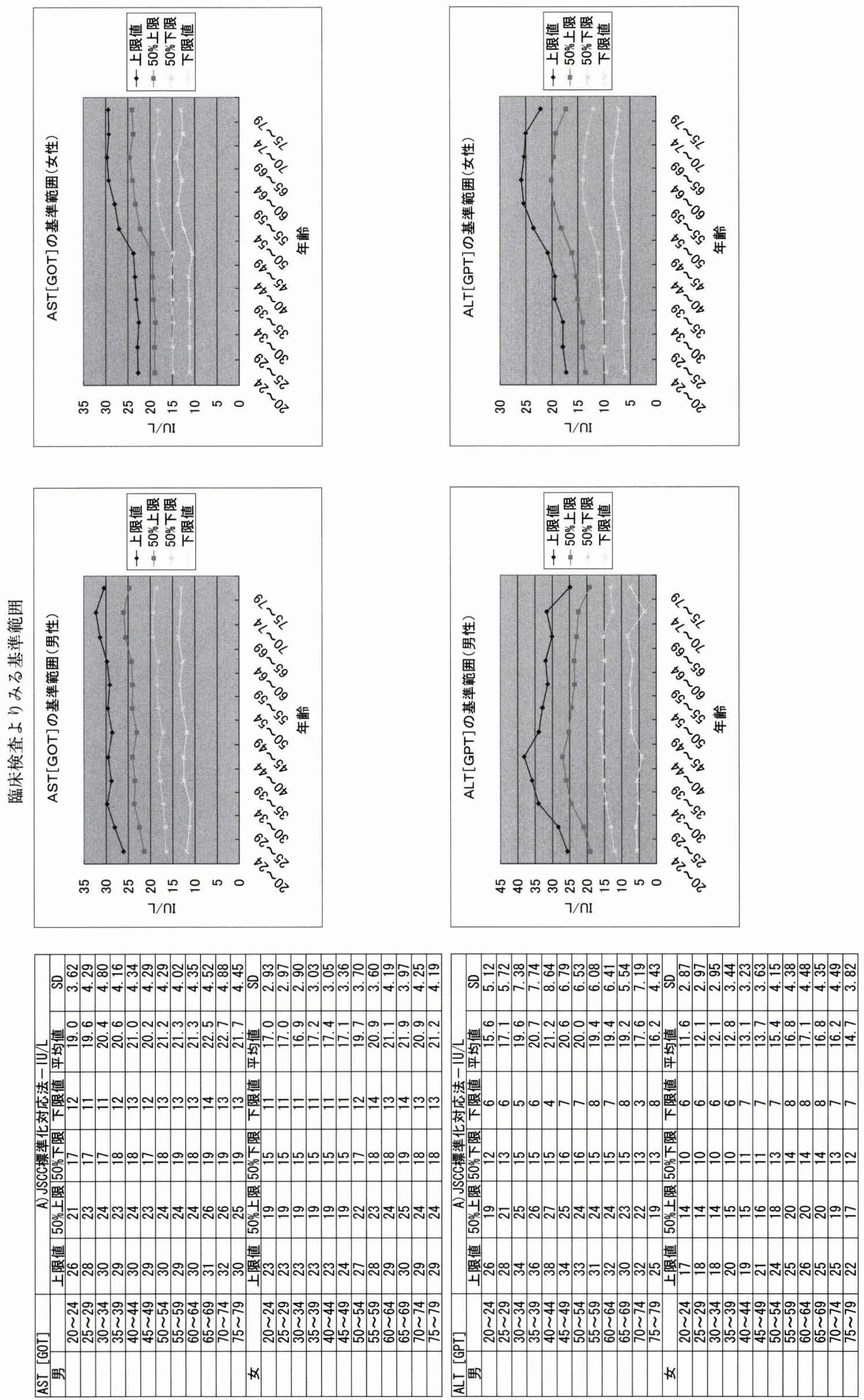

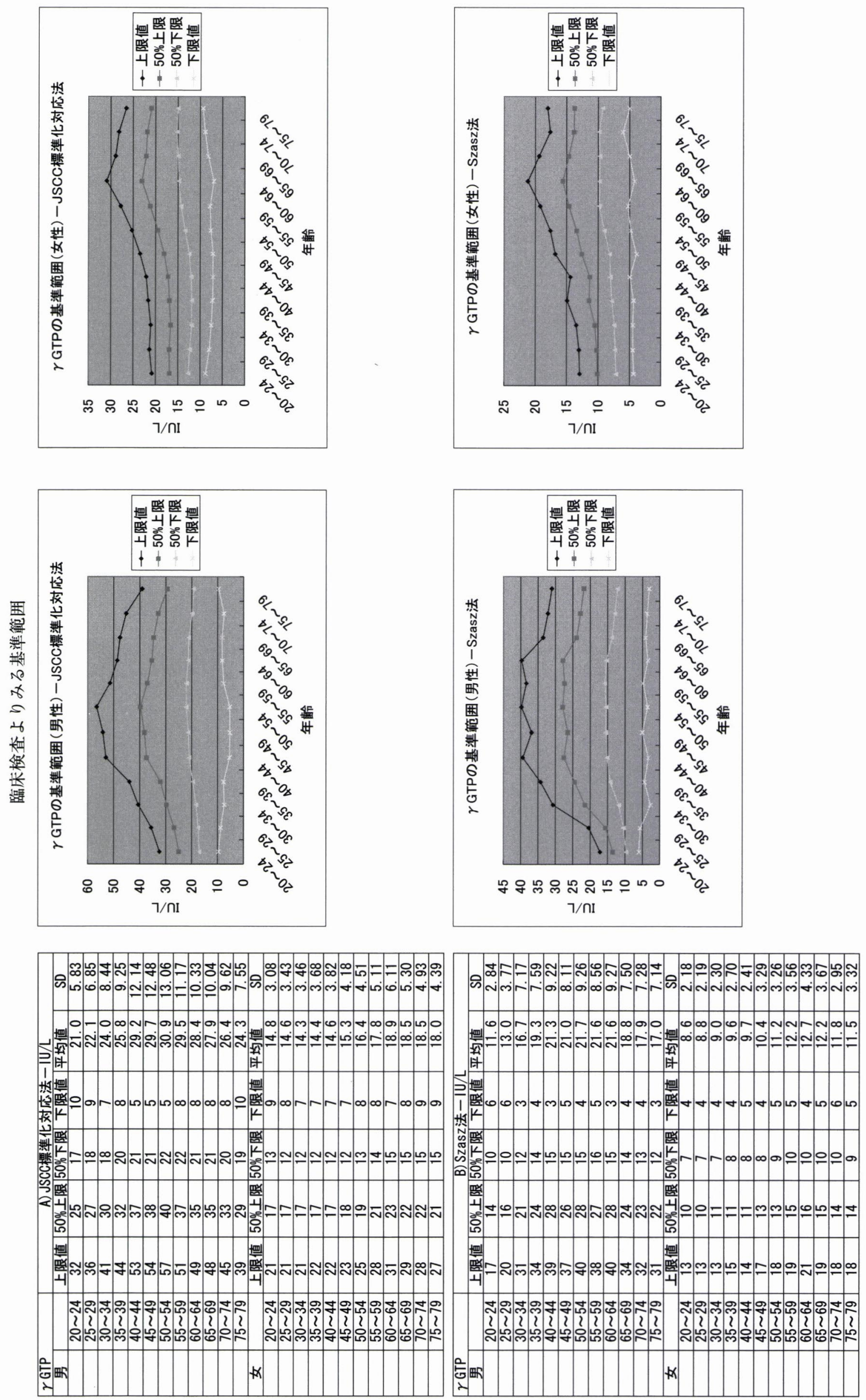

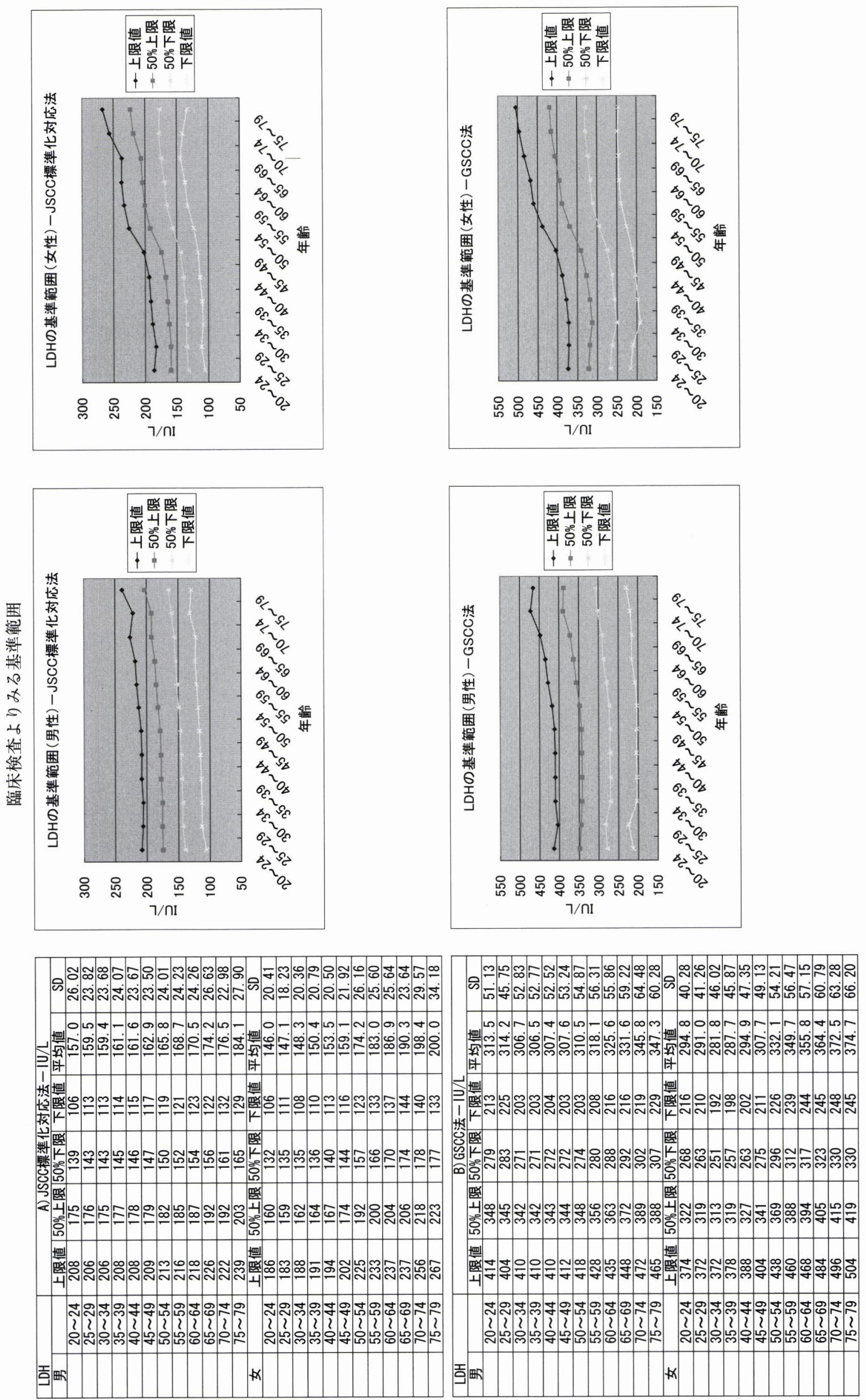

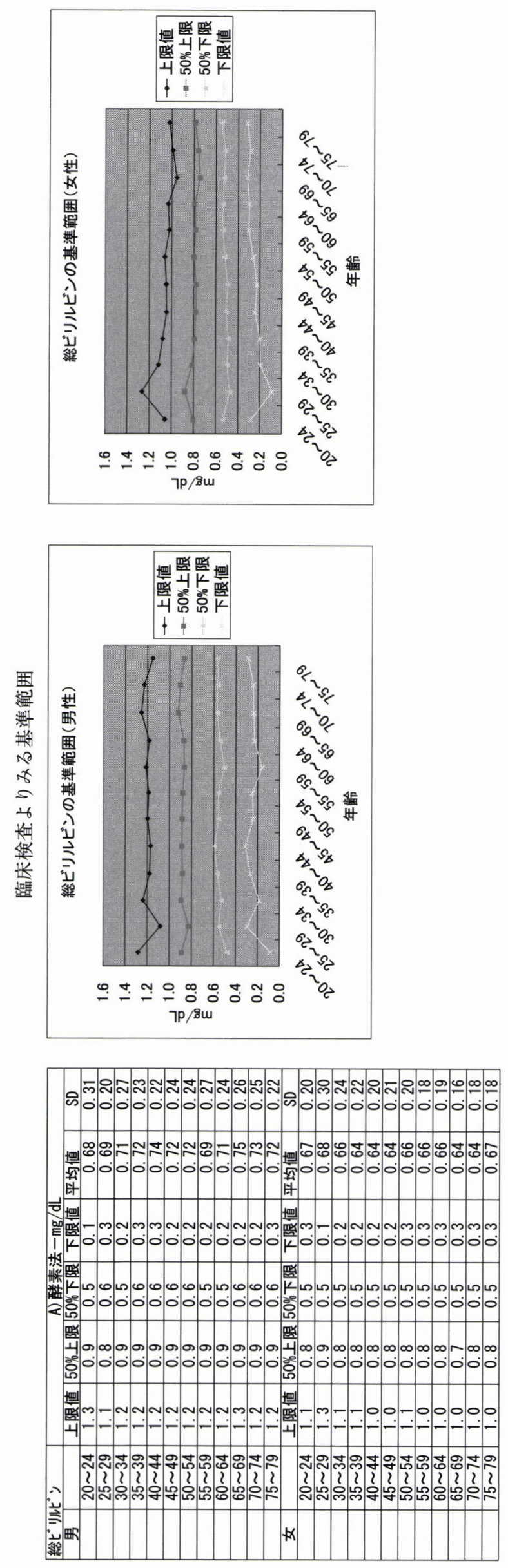
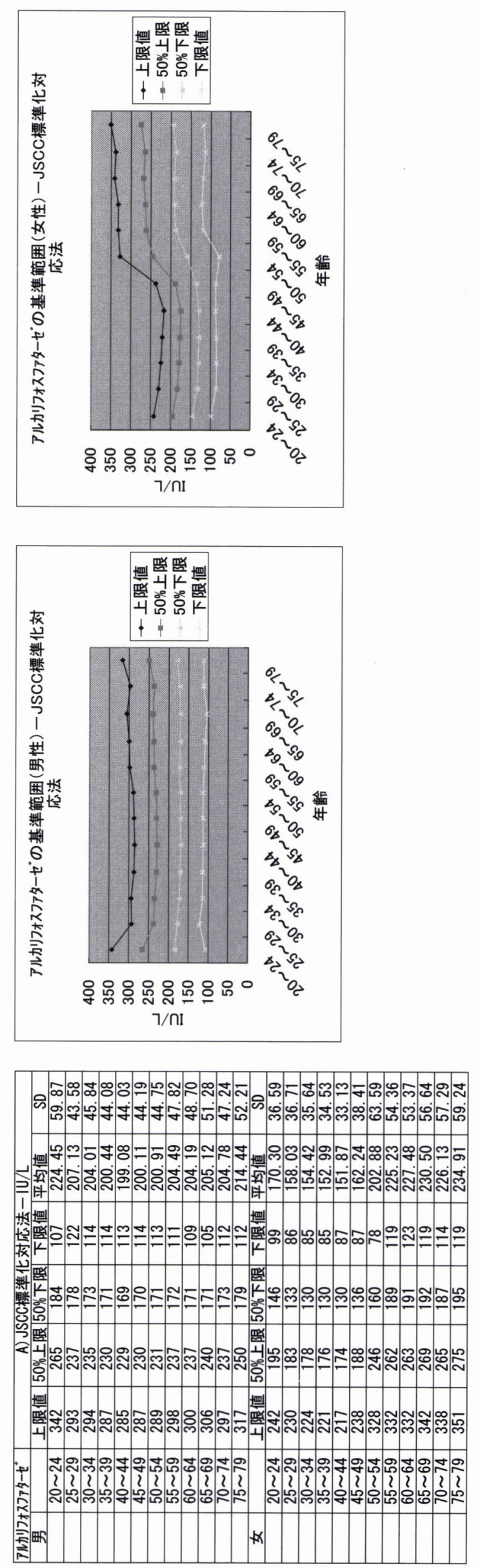

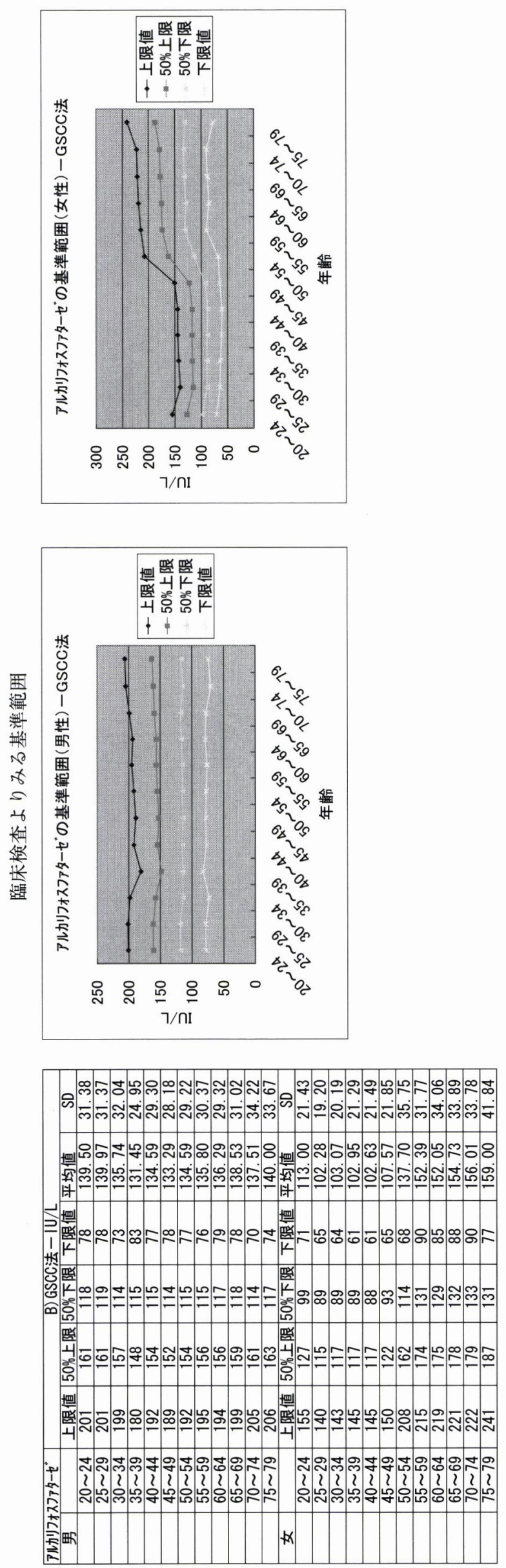
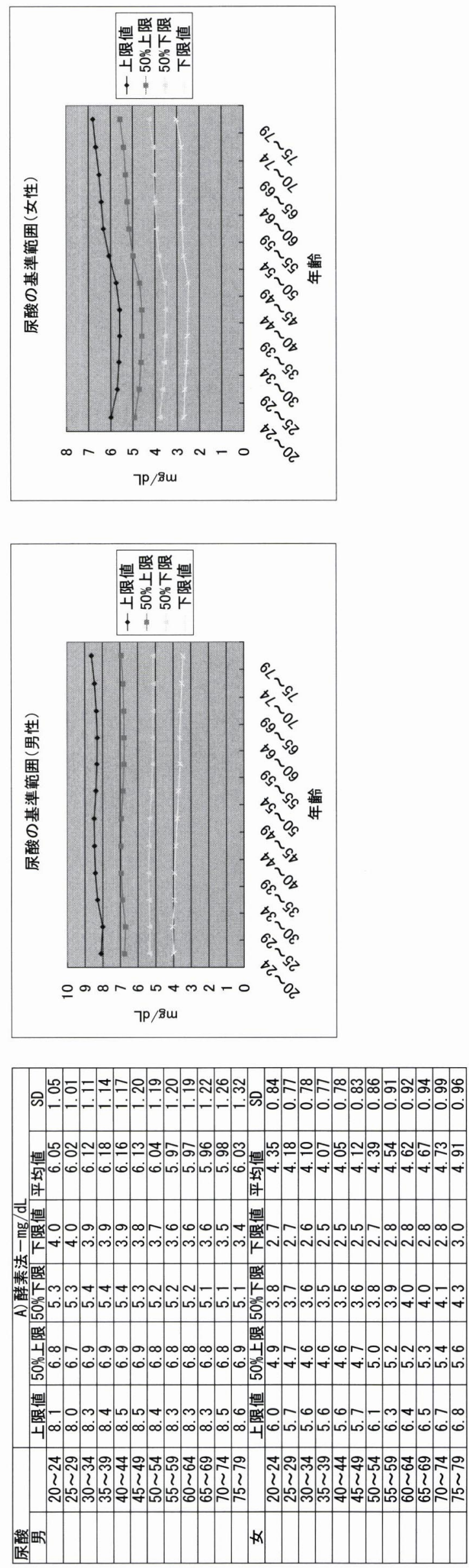

(545) 41 

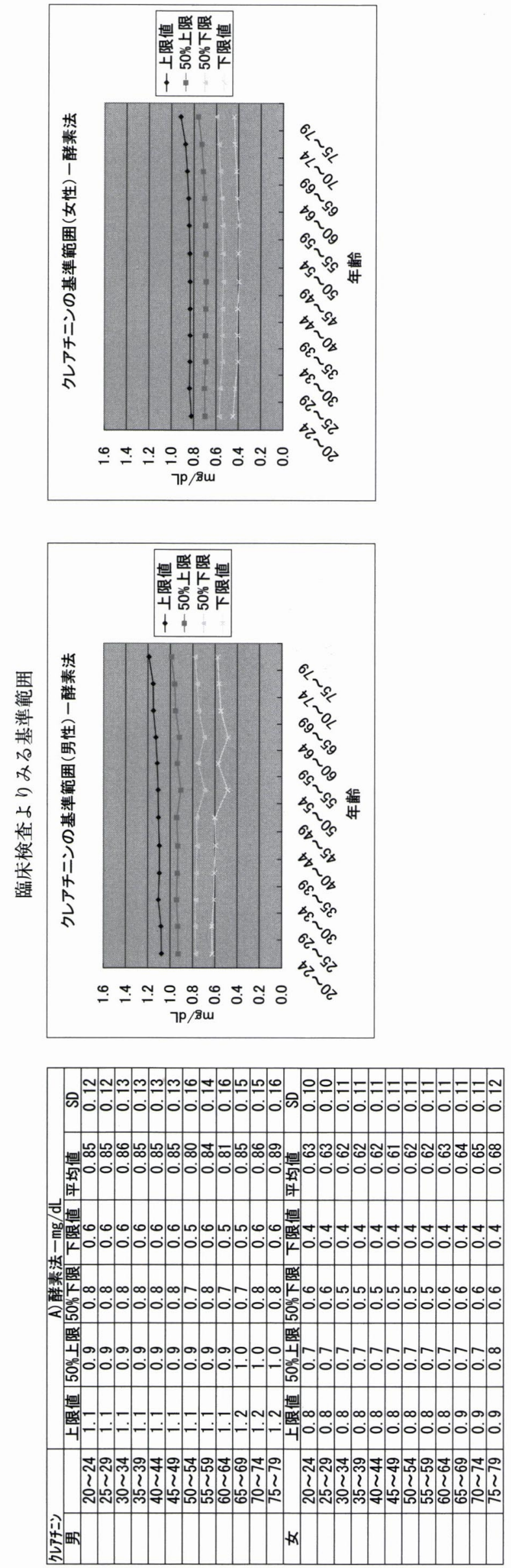
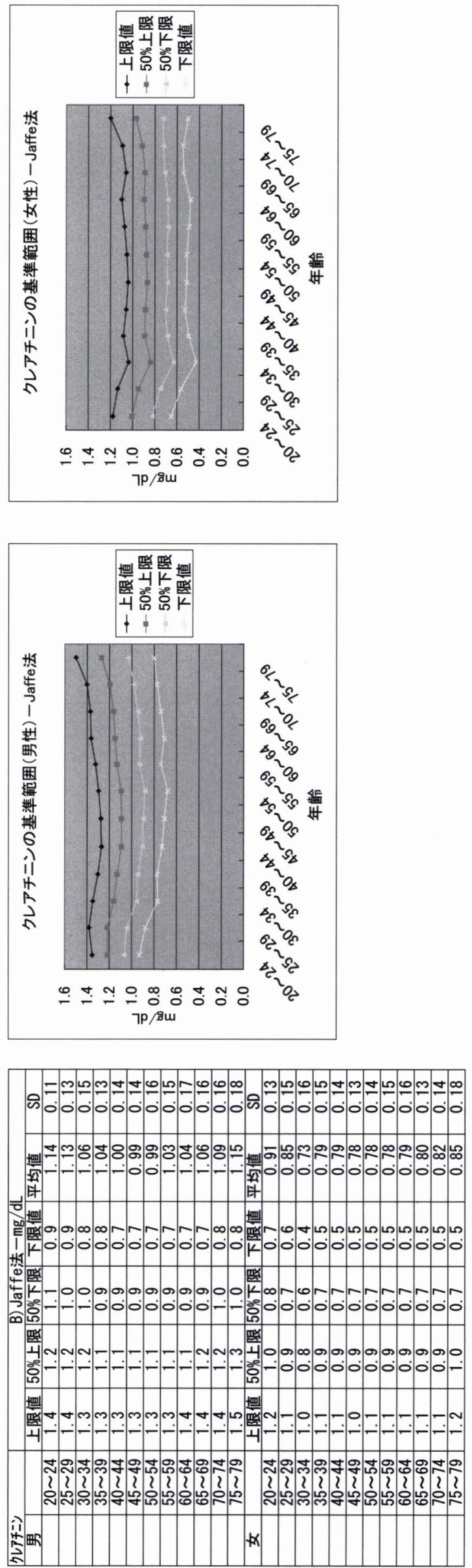

HEP Vol. 34, No. 5, 2007 

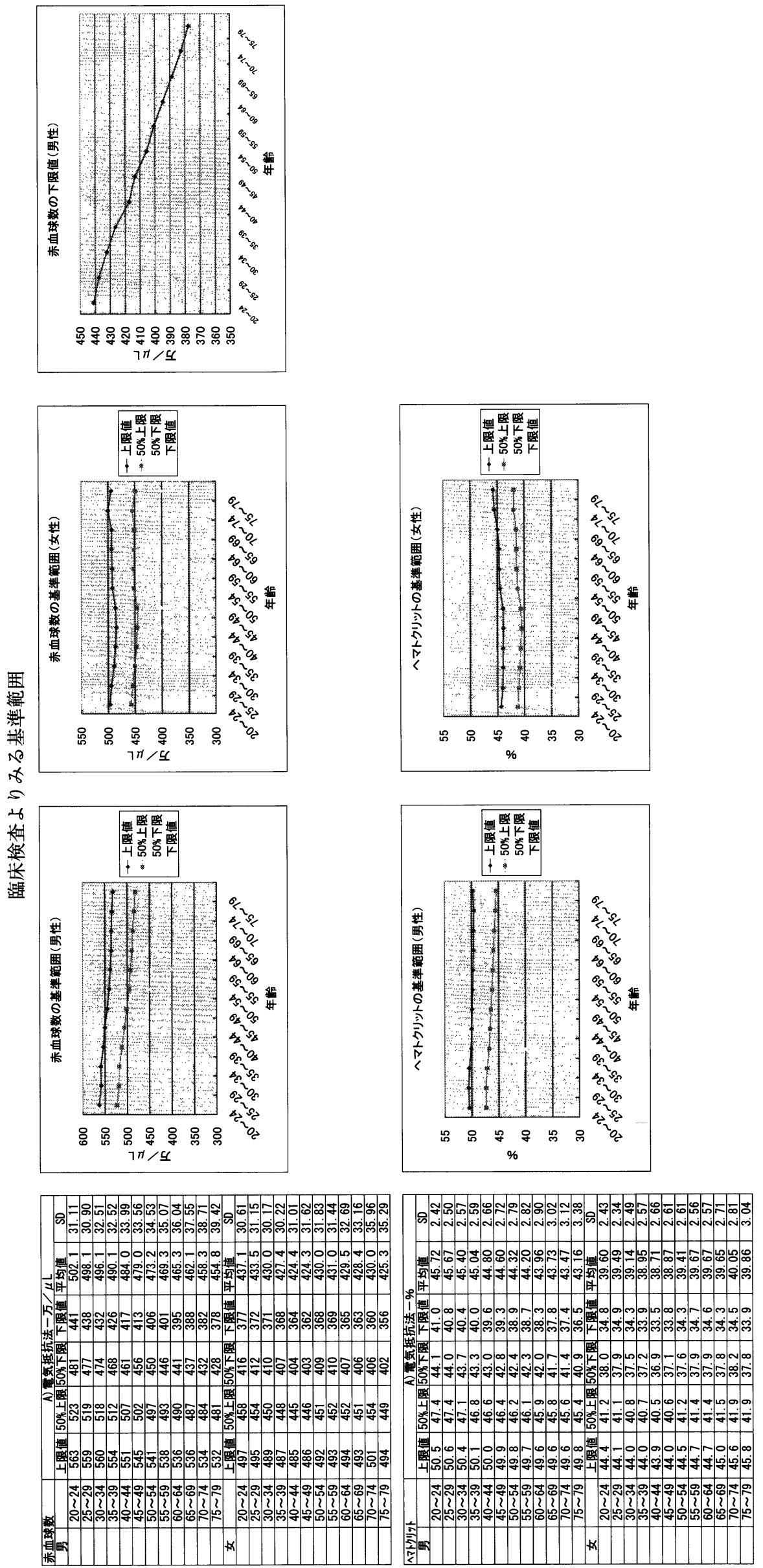

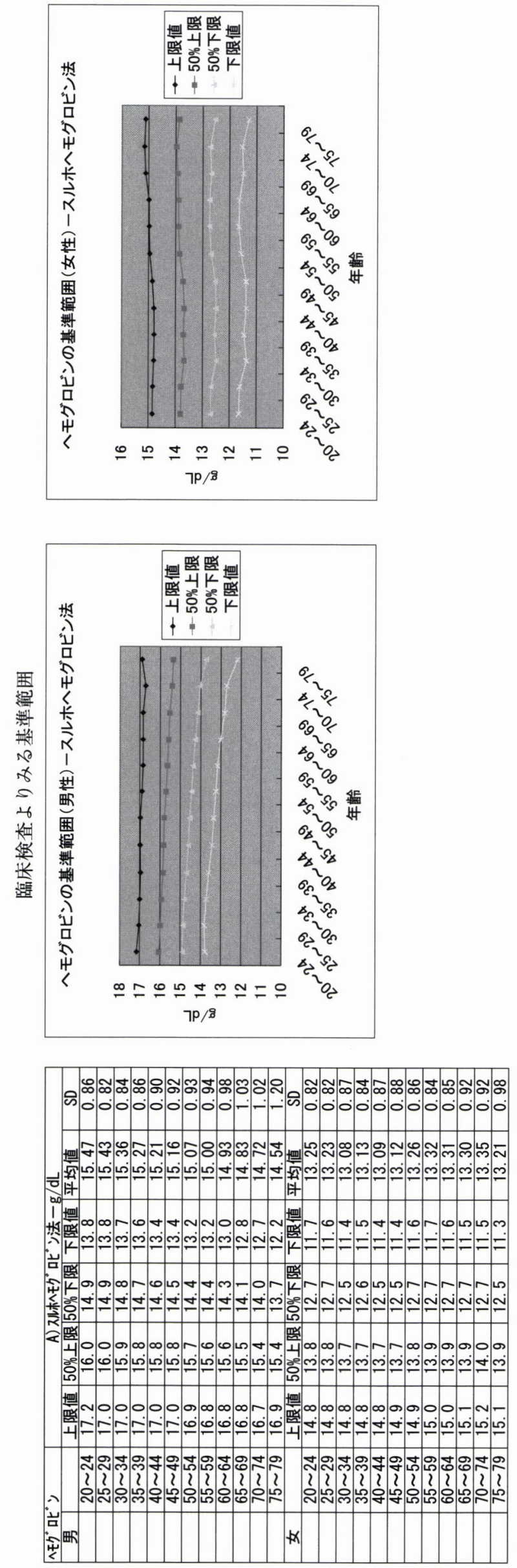
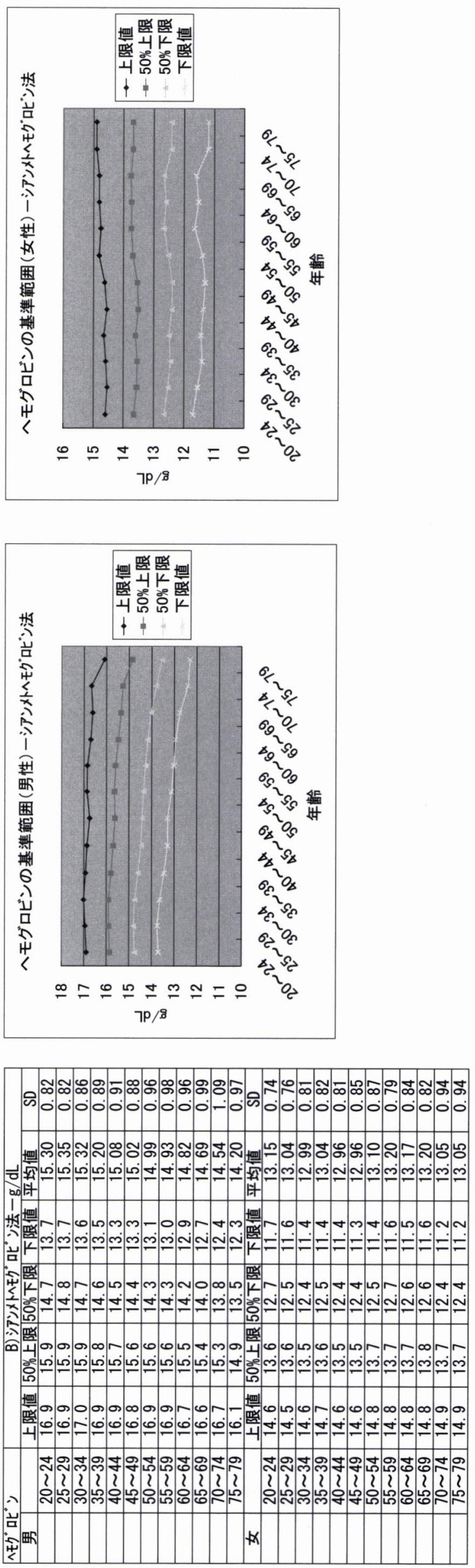

HEP Vol. 34, No. 5, 2007 

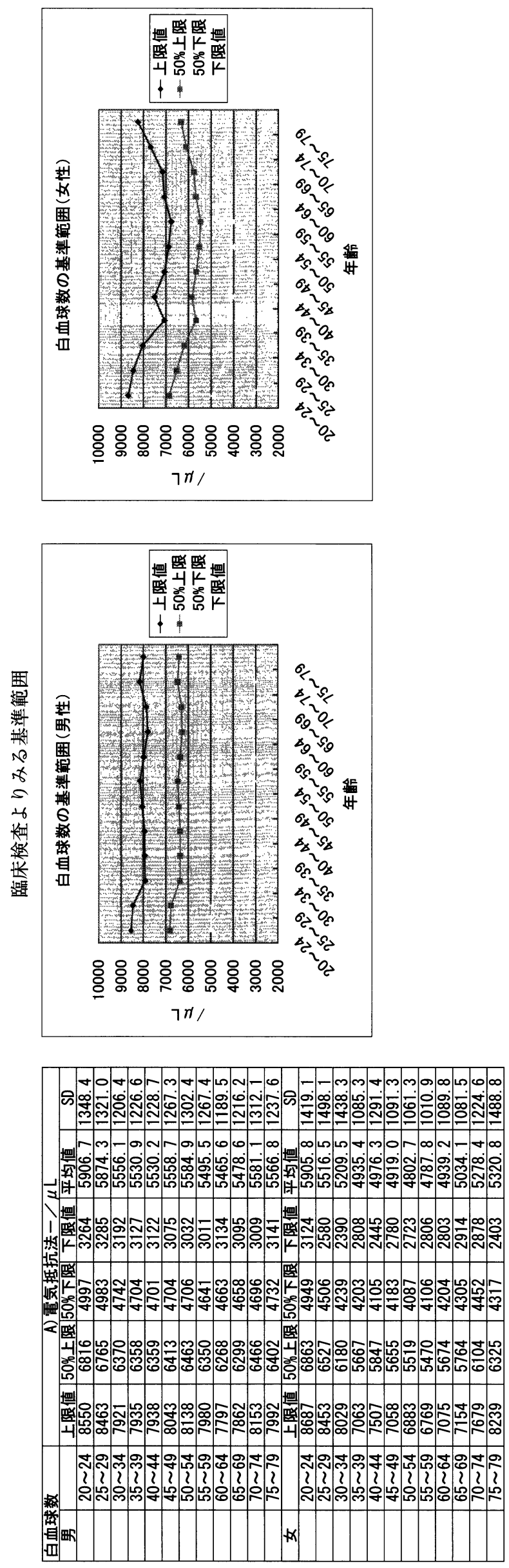
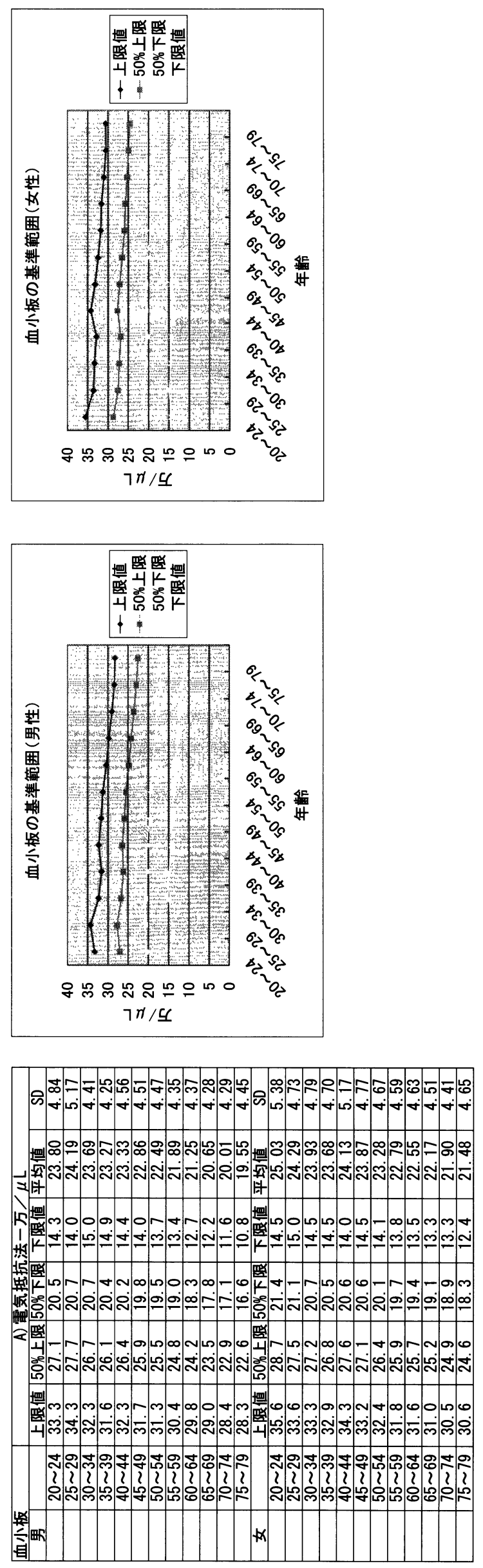

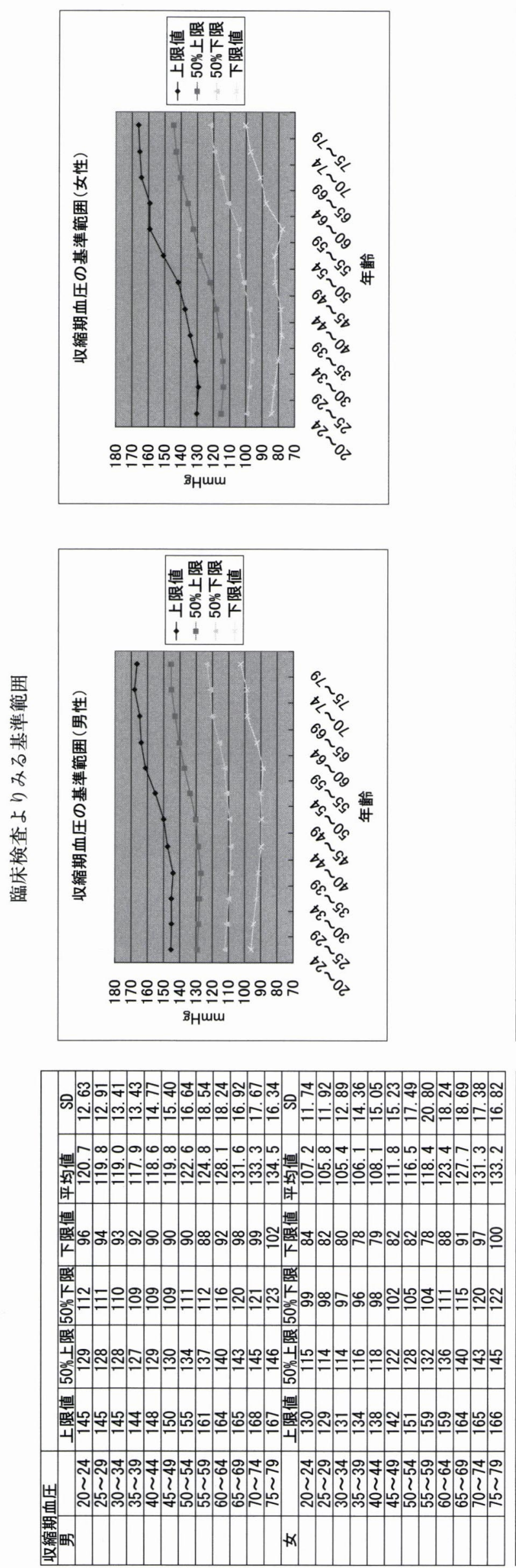
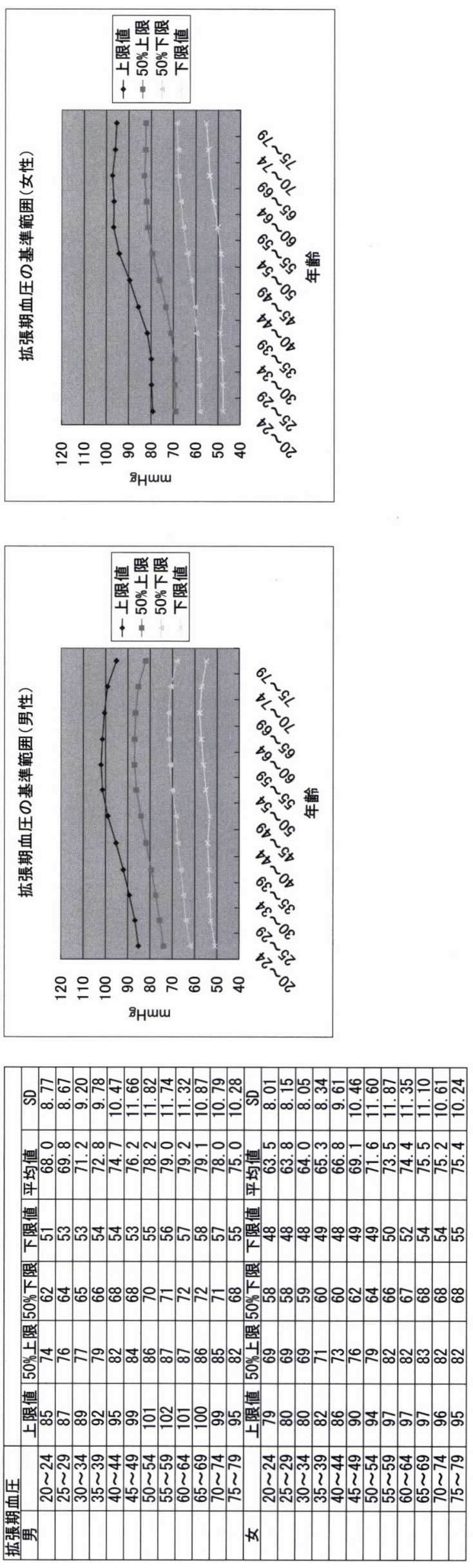

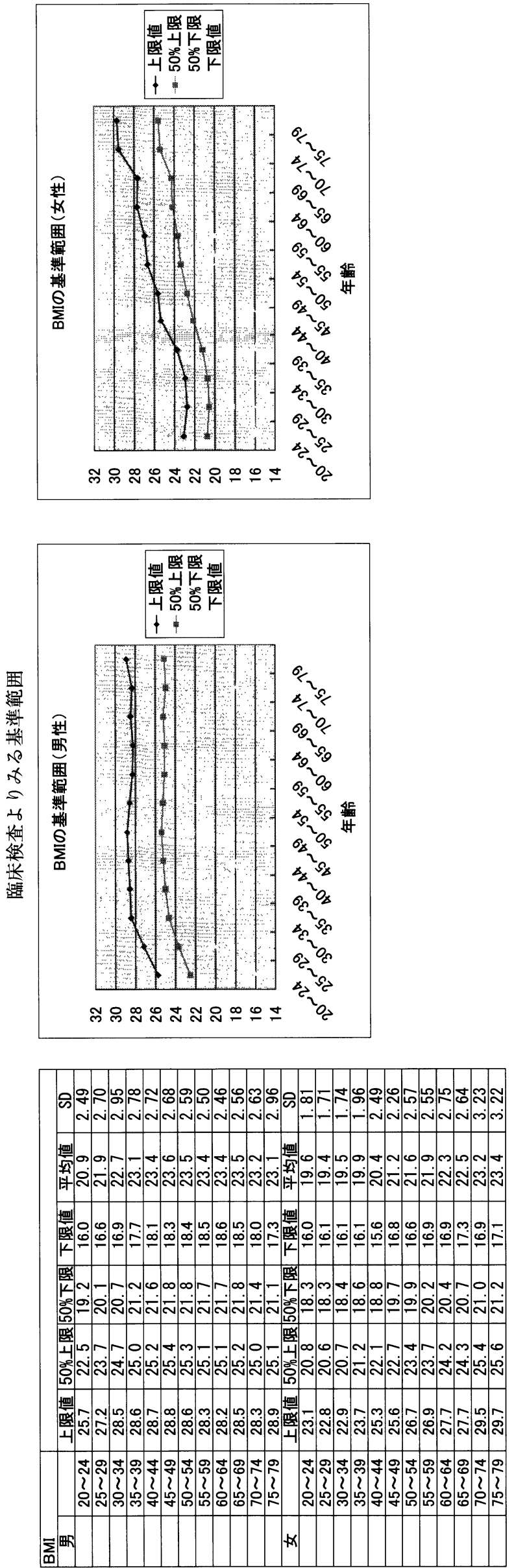
男性 20 24歳

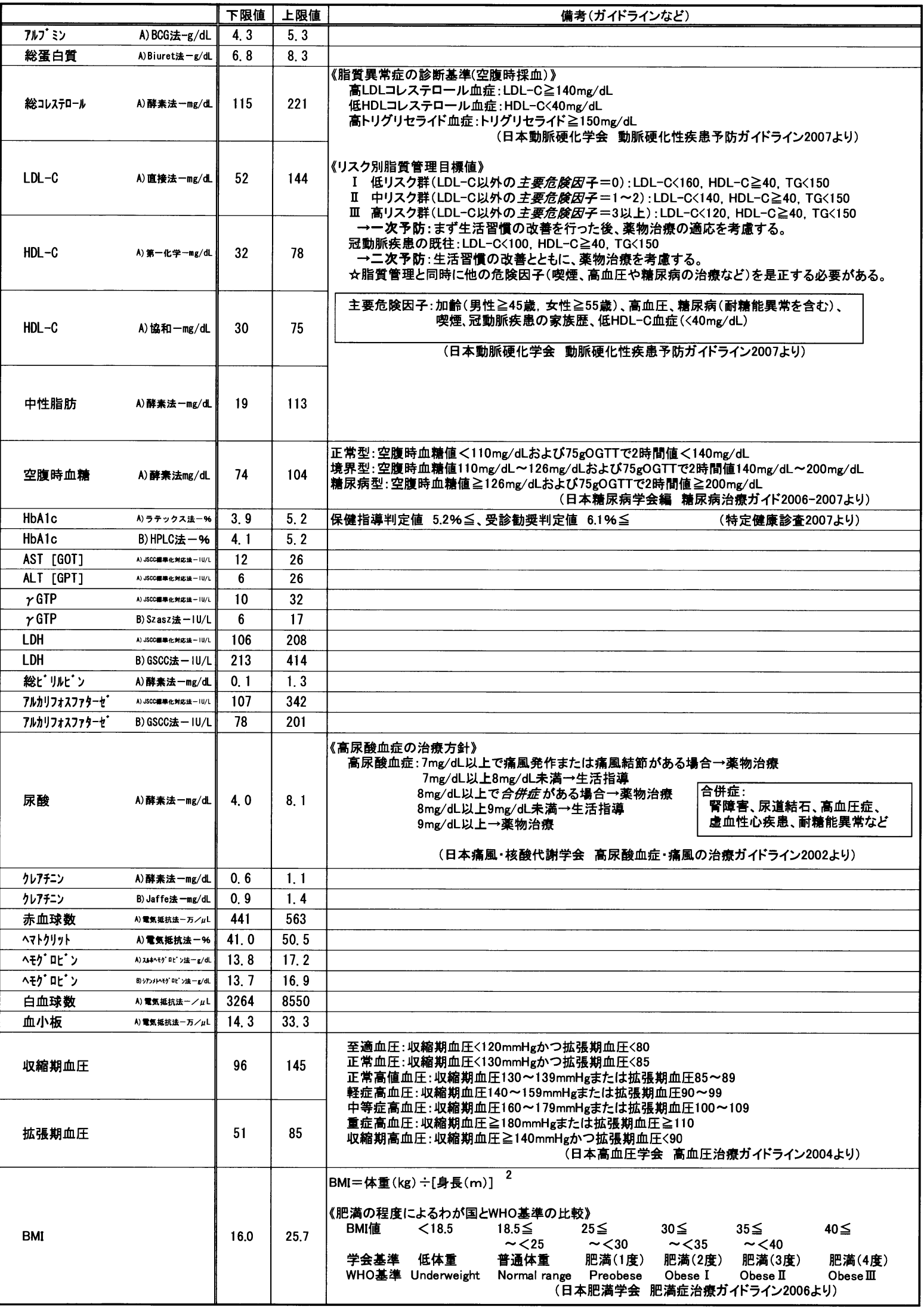


男性 25 29歳

\begin{tabular}{|c|c|c|c|c|}
\hline & & 下限値 & 上限値 & 備考(ガイドラインなど) \\
\hline Pルプシ & A) BCG法-g/dL & 4.3 & 5.3 & \\
\hline 総蛋白質 & A) Biuret法 $-g / d t$ & 6.7 & 8.2 & \\
\hline 総コレステロロ-ル & A)酔素法 $-\mathrm{mg} / \mathrm{dL}$ & 122 & 235 & 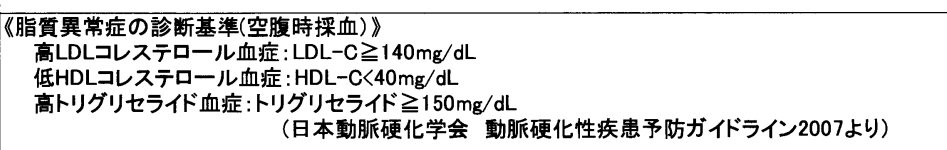 \\
\hline LDL-C & A) 直接法 $-\mathrm{mg} / \mathrm{dL}$ & 58 & 155 & \multirow{2}{*}{ 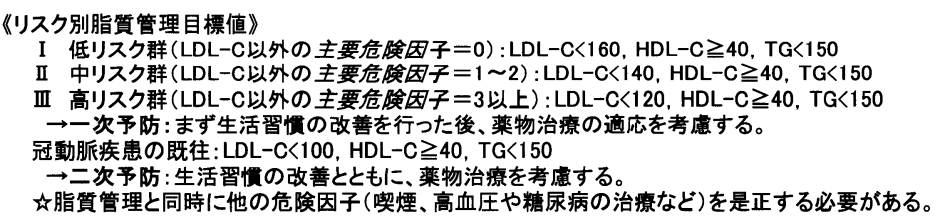 } \\
\hline HDL-C & A) 第一化 $=-\mathrm{m} / \mathrm{m} / \mathrm{dL}$ & 31 & 77 & \\
\hline HDL-C & A) 協和 $-\mathrm{mg} / \mathrm{dL}$ & 28 & 75 & 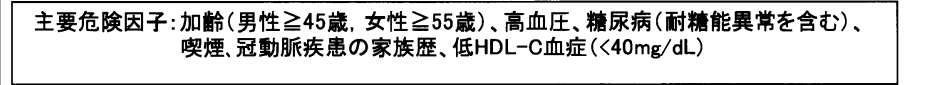 \\
\hline & & & & \multirow[t]{2}{*}{ 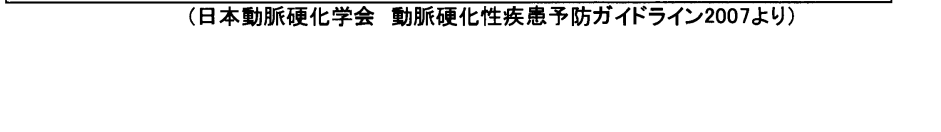 } \\
\hline 中性脂肪 & 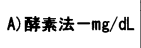 & 23 & 119 & \\
\hline 空腹時血糖 & A) 酜素法的/dL & 78 & 104 & 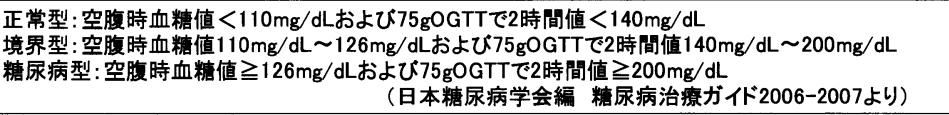 \\
\hline HbA1c & A)ラテッククス法ー 96 & 3.9 & 5.2 & 保健指導判定値 $5.2 \% \leqq 、$ 受診勧奖判定値 $6.1 \% \leqq$ \\
\hline HbAlc & B) HPLC法 $-\%$ & 4.1 & 5.2 & \\
\hline AST [GOT] & 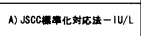 & 11 & 28 & \\
\hline ALT [GPT] & 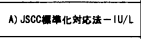 & 6 & 28 & \\
\hline$r$ GTP & 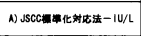 & 9 & 36 & \\
\hline$r$ GTP & B) Szasz法-IU/L & 6 & 20 & \\
\hline LDH & 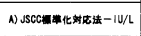 & 113 & 206 & \\
\hline LDH & B) GSCC法 $-1 U / L$ & 225 & 404 & \\
\hline 総ビリ㸝・ン & A) 酥素法-mg/dL & 0.3 & 1.1 & \\
\hline アルかリフォスフアターセ゚ & 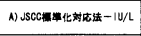 & 122 & 293 & \\
\hline フルかリフォスファターセ゚ & B) GSCC法－IU/L & 78 & 201 & \\
\hline 尿酸 & A)酝素法 $-\mathrm{mg} / \mathrm{dL}$ & 4. 0 & 8.0 & 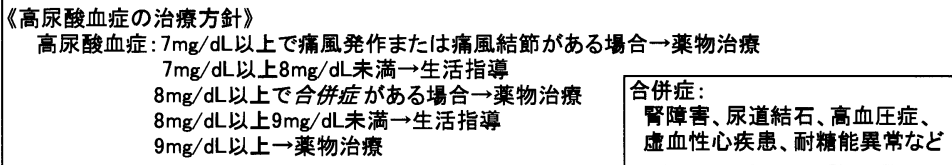 \\
\hline & & & & (日本痛風·核酸代謝学会 高尿酸血症·痛風の治療ガイドライン2002より) \\
\hline クレフテニン & A)酝素法一 $\mathrm{mg} / \mathrm{dL}$ & 0.6 & 1.1 & \\
\hline クレアチニン & B) Jaffe $=$ 法 $-\mathrm{mg} / \mathrm{dL}$ & 0.9 & 1.4 & \\
\hline 赤血球数 & 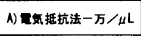 & 438 & 559 & \\
\hline ヘマトクリット & 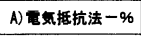 & 40.8 & 50.6 & \\
\hline ヘ告听゙ン & A) (A ) & 13.8 & 17.0 & \\
\hline ^毛方吡” & (8), & 13.7 & 16.9 & \\
\hline 白血球数 & 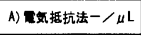 & 3285 & 8463 & \\
\hline 血小板 & 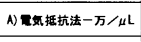 & 14.0 & 34. 3 & \\
\hline 収縮期血圧 & & 94 & 145 & 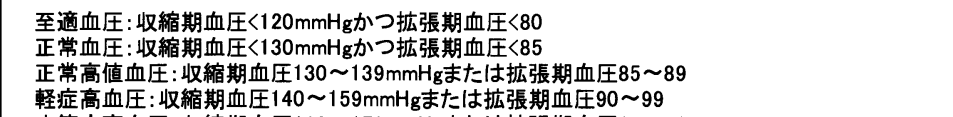 \\
\hline 拡張期血圧 & & 53 & 87 & 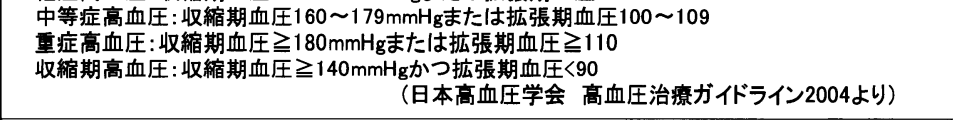 \\
\hline BMI & & 16.6 & 27.2 & 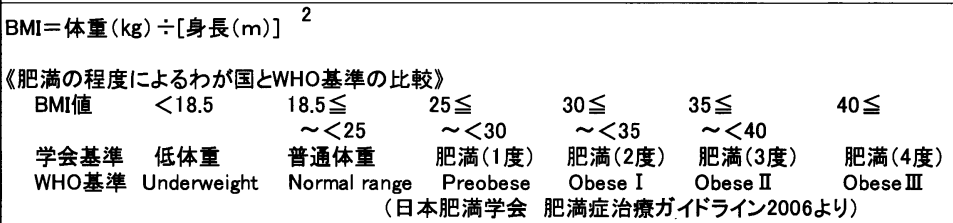 \\
\hline
\end{tabular}


男性 30 34藏

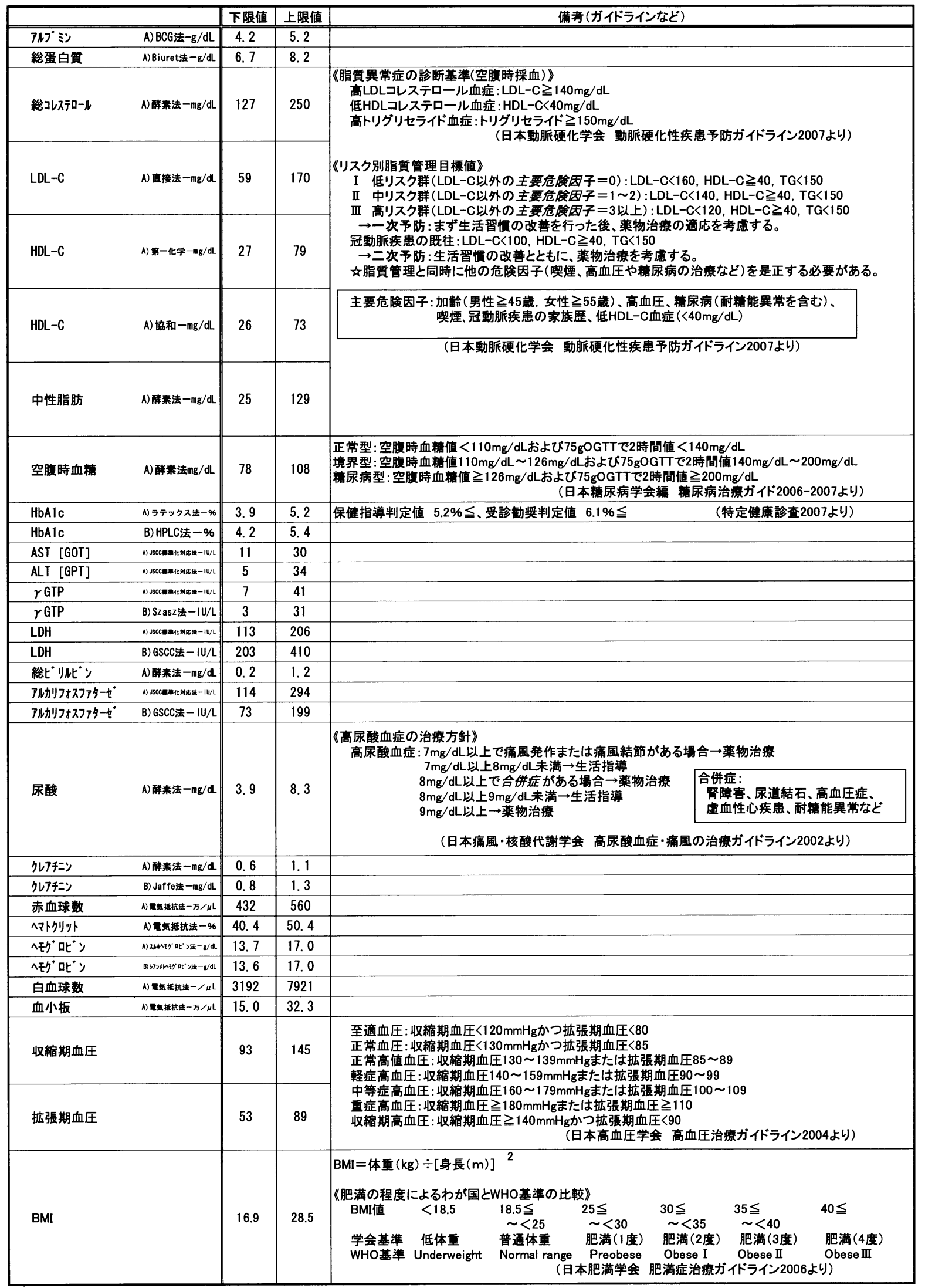




\section{基 準 䈏 囲}

男性 35 39歳

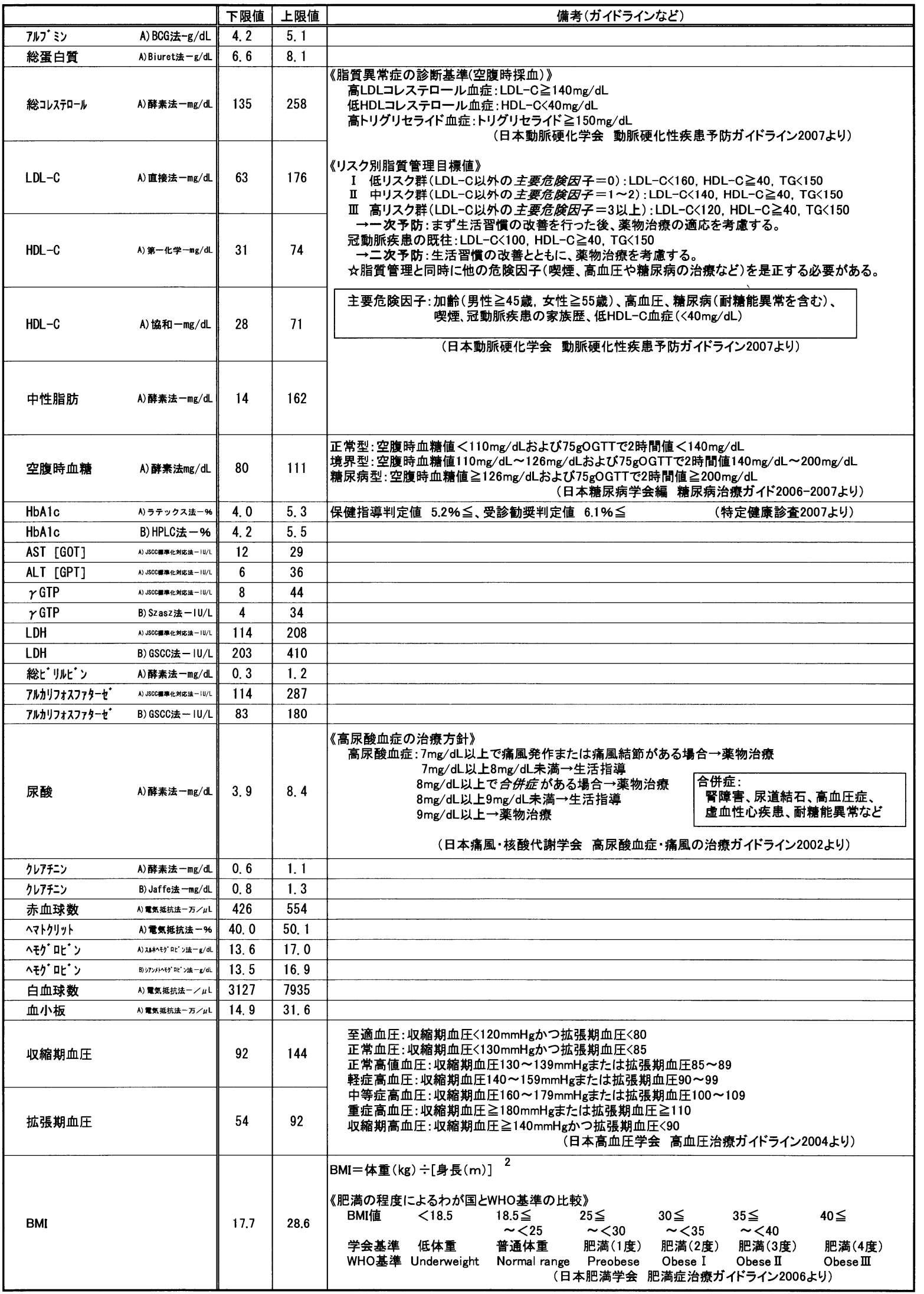




\section{基 準 笵 囲}

男性 40 44藏

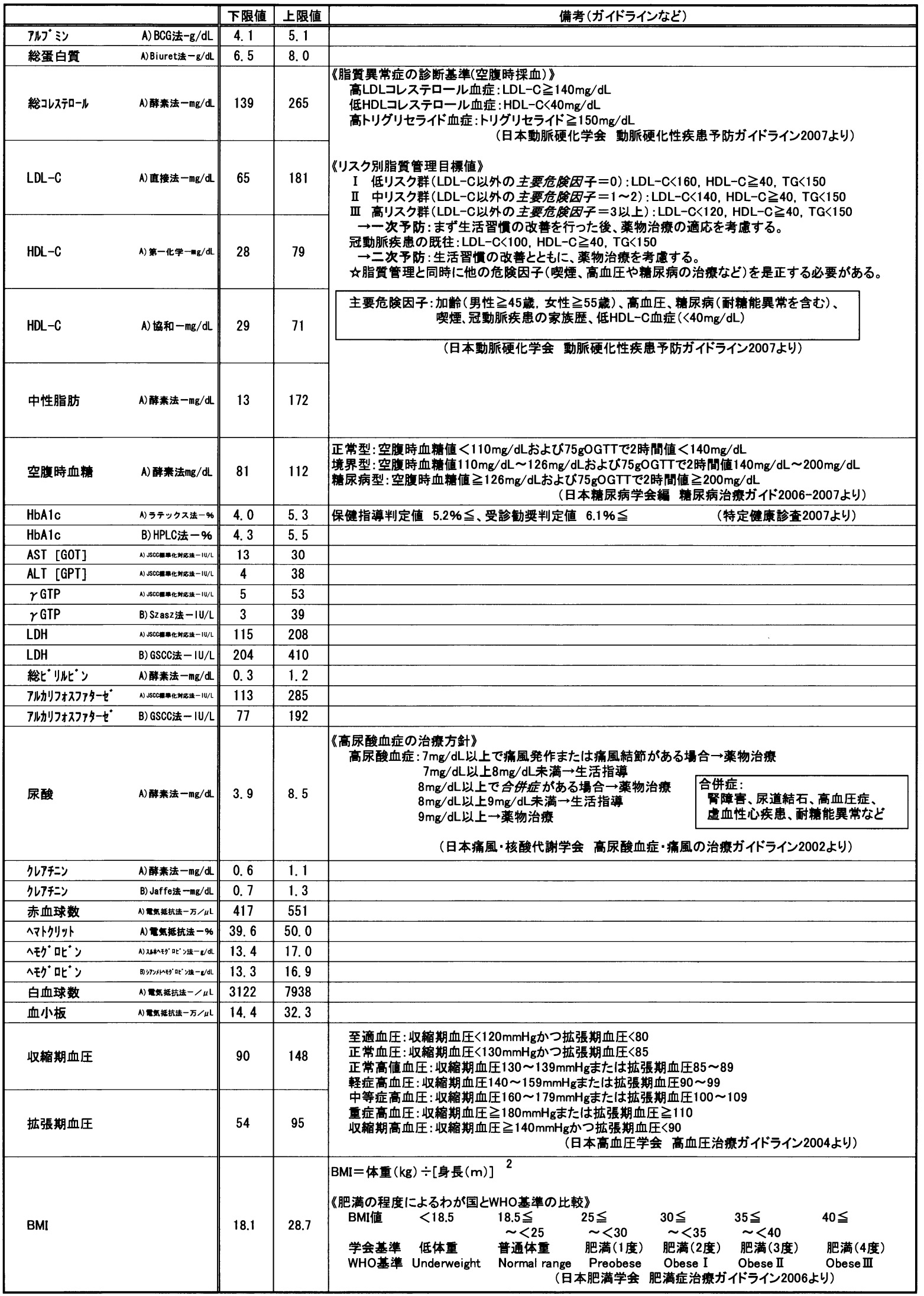


男性 45 49歳

\begin{tabular}{|c|c|c|c|c|}
\hline & & 下限値 & 上限値 & 備考(ガイドラインなど) \\
\hline 7ルプミン & A) BCG法-g/dL & 4.1 & 5.0 & \\
\hline 総蛋白質 & A) Biuret法-g/du & 6.5 & 8.0 & \\
\hline 総コしステロール & A)酝素法 $-\mathrm{mg} / \mathrm{dL}$ & 142 & 267 & \multirow{3}{*}{ 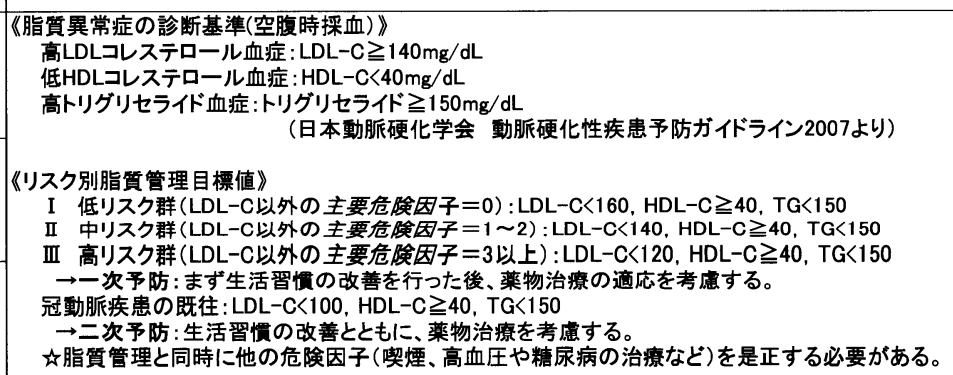 } \\
\hline LDL-C & A) 直接法 $-\mathrm{mg} / \mathrm{dL}$ & 67 & 183 & \\
\hline HDL-C & A) 第一化学- $-\mathrm{m}_{\mathrm{g}} / \mathrm{dL}$ & 32 & 75 & \\
\hline HDL-C & A) 協和 $-m g / d L$ & 29 & 71 & \multirow{2}{*}{ 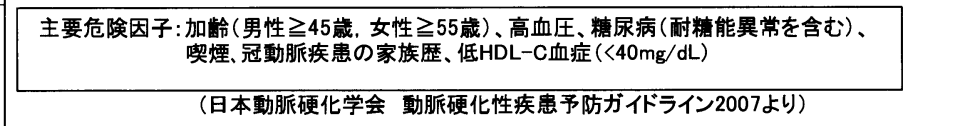 } \\
\hline & & & & \\
\hline 中性脂肪 & A)瞵素法 $-\mathrm{mg} / \mathrm{dL}$ & 7 & 194 & \\
\hline 空腹時血糖 & A) 瞵秦法mg/dL & 82 & 114 & 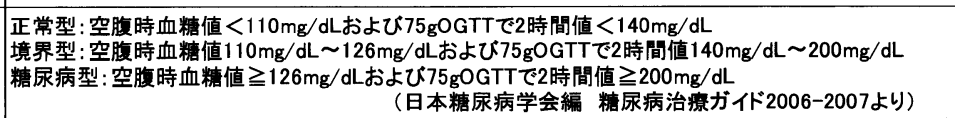 \\
\hline HbA1c & A)ラテックスス法ー96 & 4.1 & 5.4 & 保健指導判定値 $5.2 \% \leqq$ 、受診钓䍘判定値 $6.1 \% \leqq$ \\
\hline HbAIC & B) HPLC法 - \% & 4.3 & 5.6 & \\
\hline AST [GOI] & 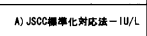 & 12 & 29 & \\
\hline ALT [GPT] & 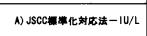 & 7 & 34 & \\
\hline$\gamma$ GTP & 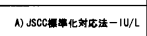 & 5 & 54 & \\
\hline$r$ GTP & B) Szasz法-IU/L & 5 & 37 & \\
\hline LDH & 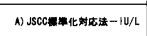 & 117 & 209 & \\
\hline LDH & B) GSCC法-IU/L & 203 & 412 & \\
\hline 総ビ リルピン & A)酝素法 $-\mathrm{mg} / \mathrm{dL}$ & 0.2 & 1.2 & \\
\hline アルかリフォスファターゼ & A) $\sec$ A & 114 & 287 & \\
\hline アルかリフォスフアターゼ & B) GSCC法-IU/L & 78 & 189 & \\
\hline 尿酸 & A) 醇素法 $-m g / d L$ & 3.8 & 8.5 & 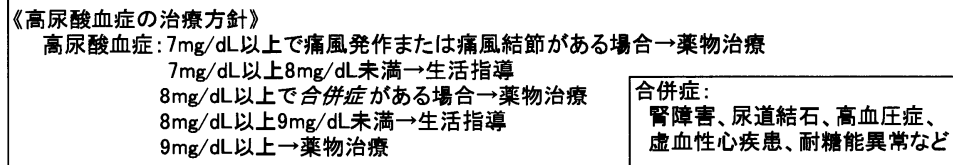 \\
\hline & & & & (日本痛風・核酸代謝学会 高尿酸血症·痛風の治療ガイドライン2002より) \\
\hline クレアチニン & A)酝素法-mg/dL & 0.6 & 1.1 & \\
\hline クレアチニン & B) Jaffe; $;$ - mg/dL & 0.7 & 1.3 & \\
\hline 赤血球数 & 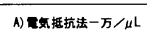 & 413 & 545 & \\
\hline ヘマトク缶师 & 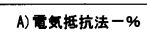 & 39.3 & 49.9 & \\
\hline ヘモグ听ン & A) & 13.4 & 17.0 & \\
\hline ヘモグ吡ン & (1):3ry & 13.3 & 16.8 & \\
\hline 白血球数 & 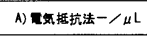 & 3075 & 8043 & \\
\hline 血小板 & 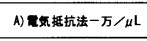 & 14.0 & 31.7 & \\
\hline 収縮期血圧 & & 90 & 150 & 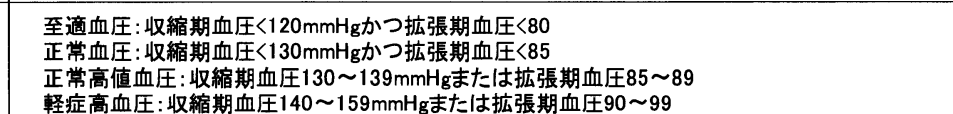 \\
\hline 拡張期血圧 & & 53 & 99 & 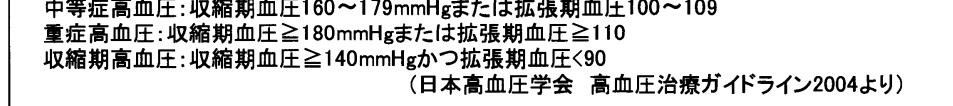 \\
\hline BMI & & 18.3 & 28.8 & 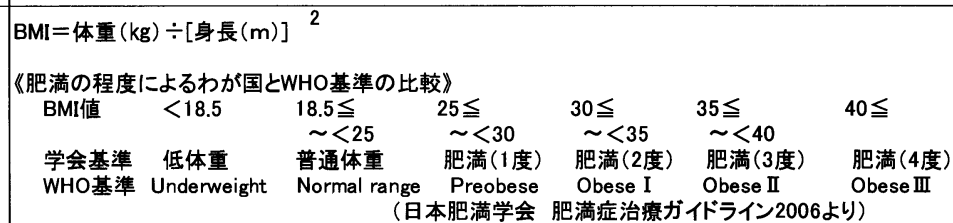 \\
\hline
\end{tabular}


男性 $50 \sim 54$ 歳

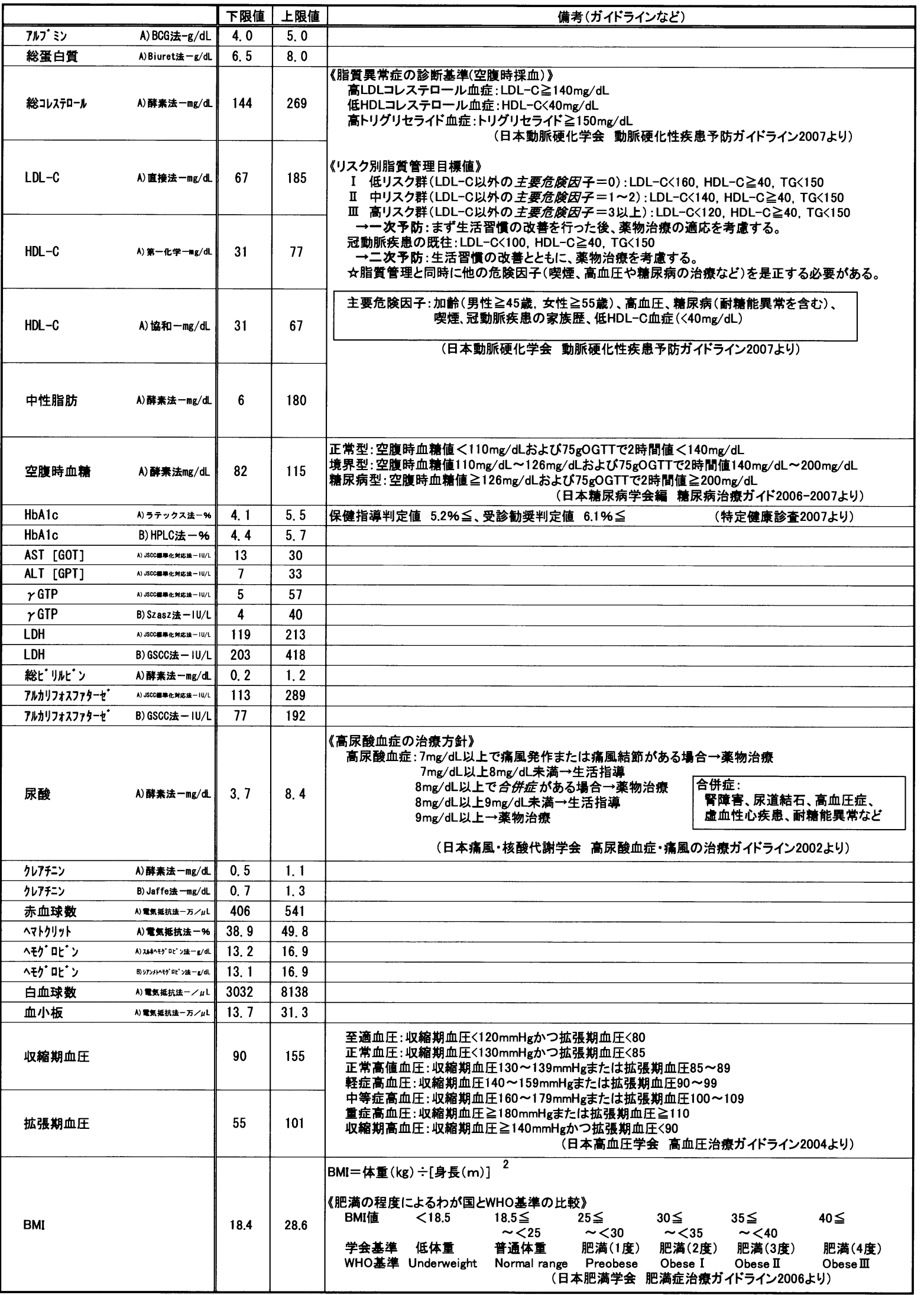


男性 55 59歳

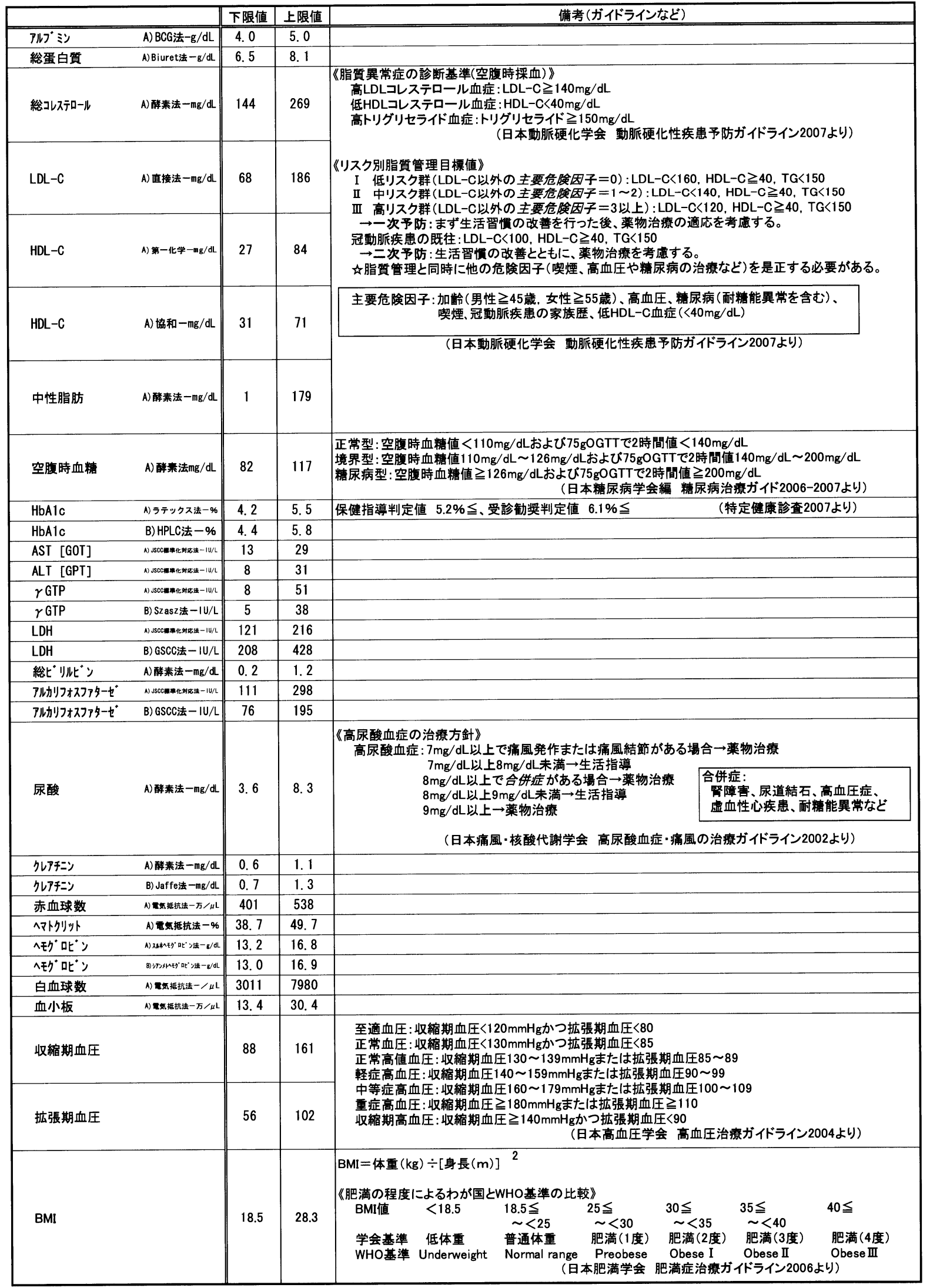


男性 60 64藏

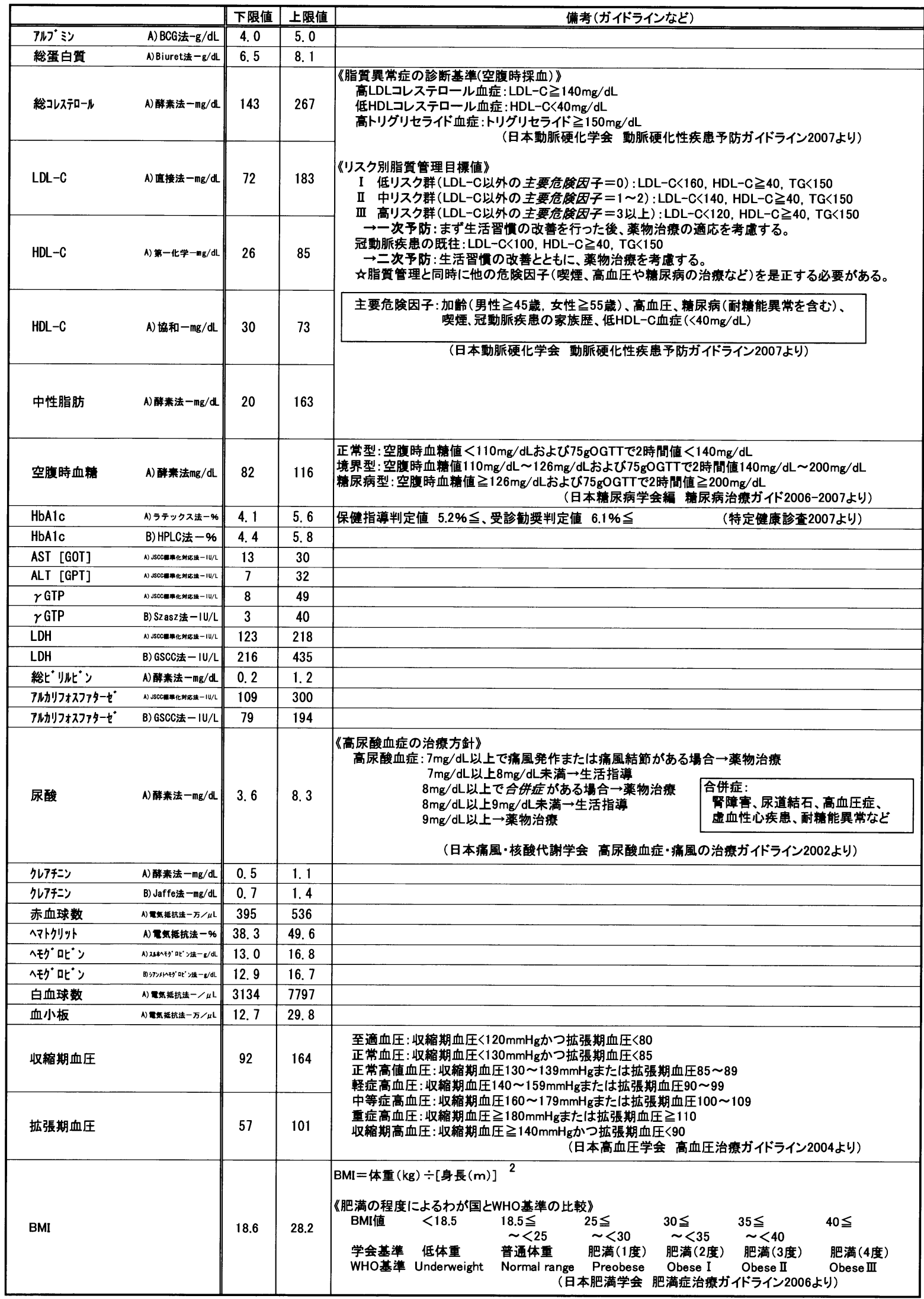


男性 65 69歳

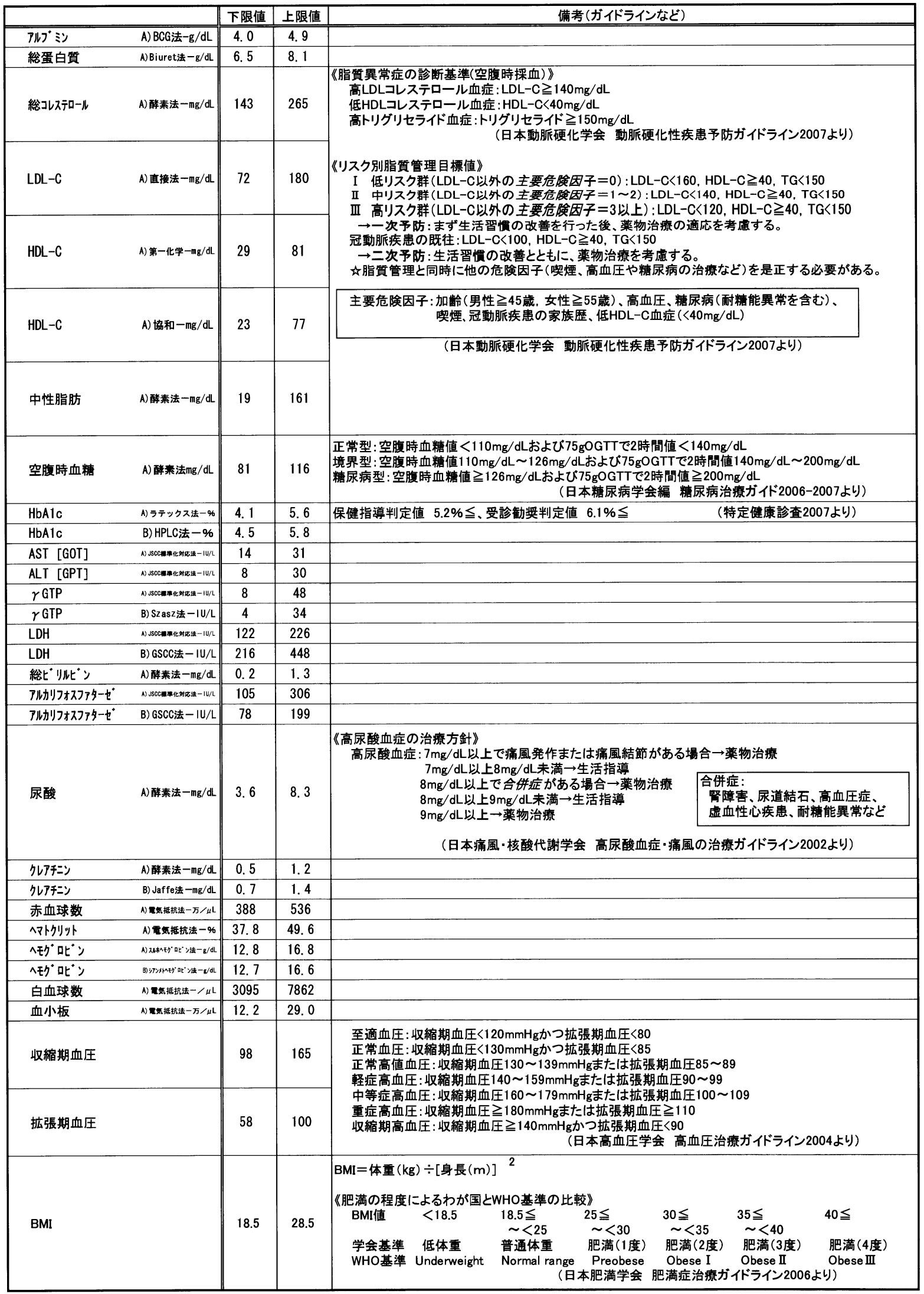


男性 70 74歳

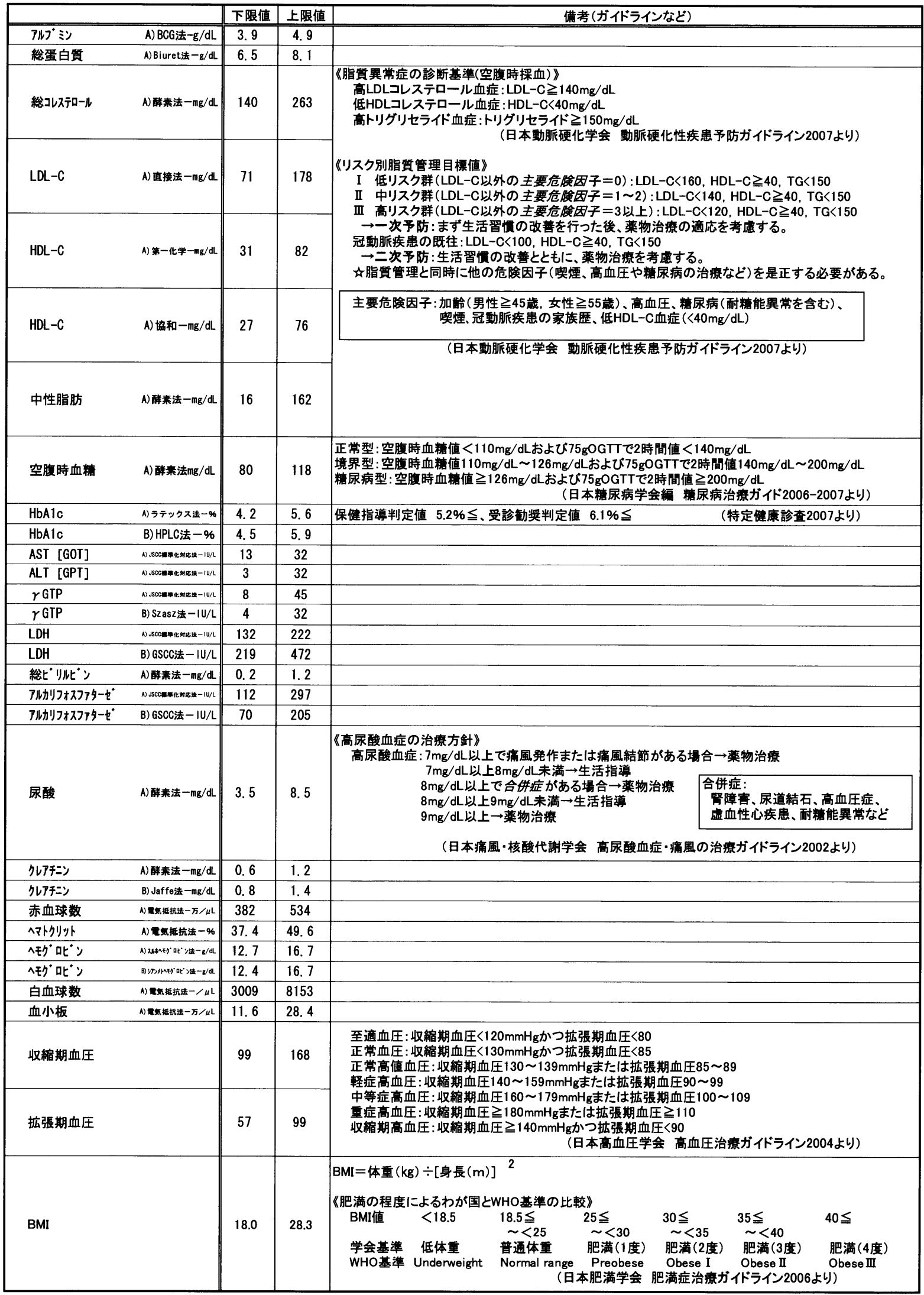




\section{基 準 筑 囲}

男性 75 79歳

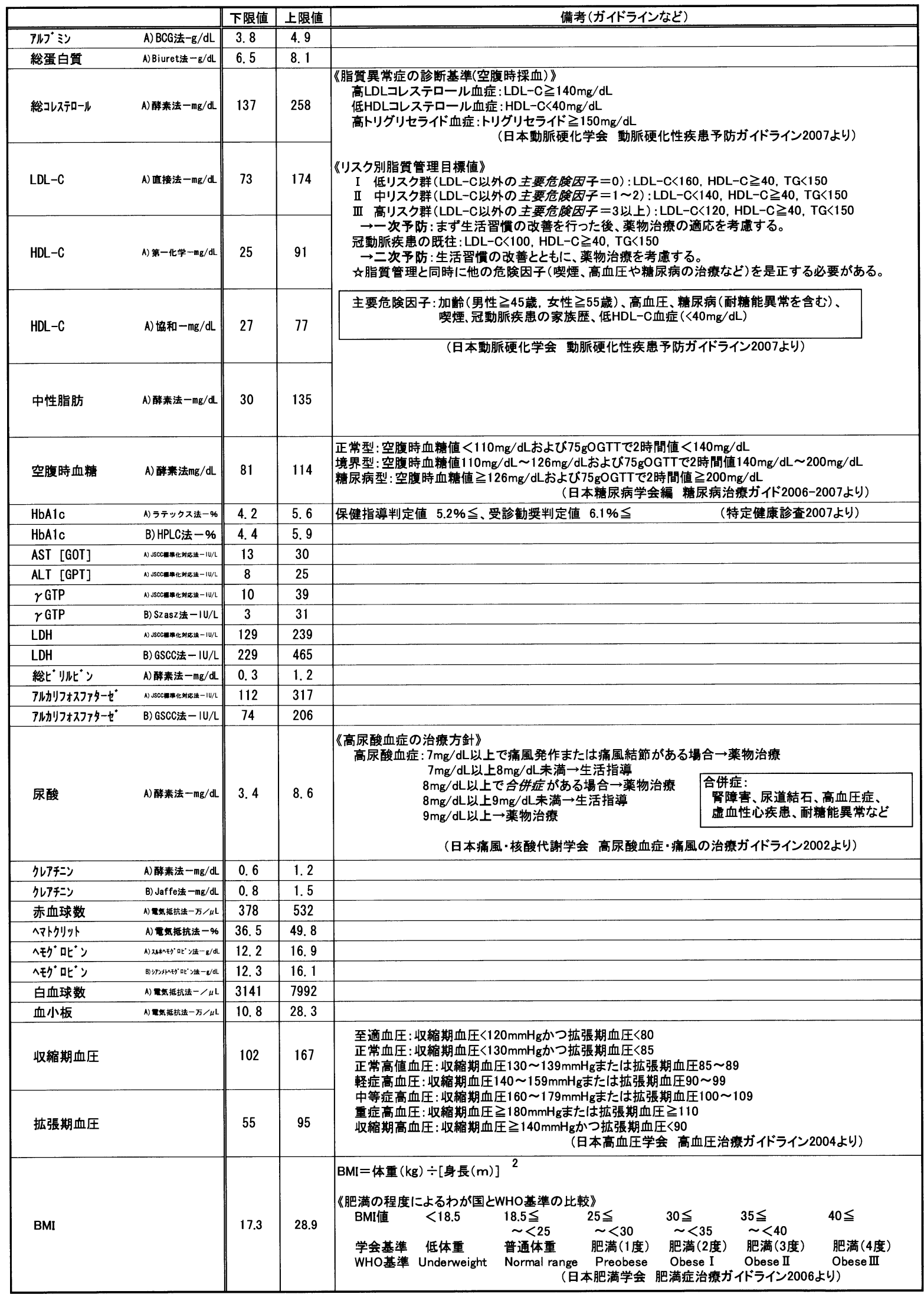


女性 20～24歳

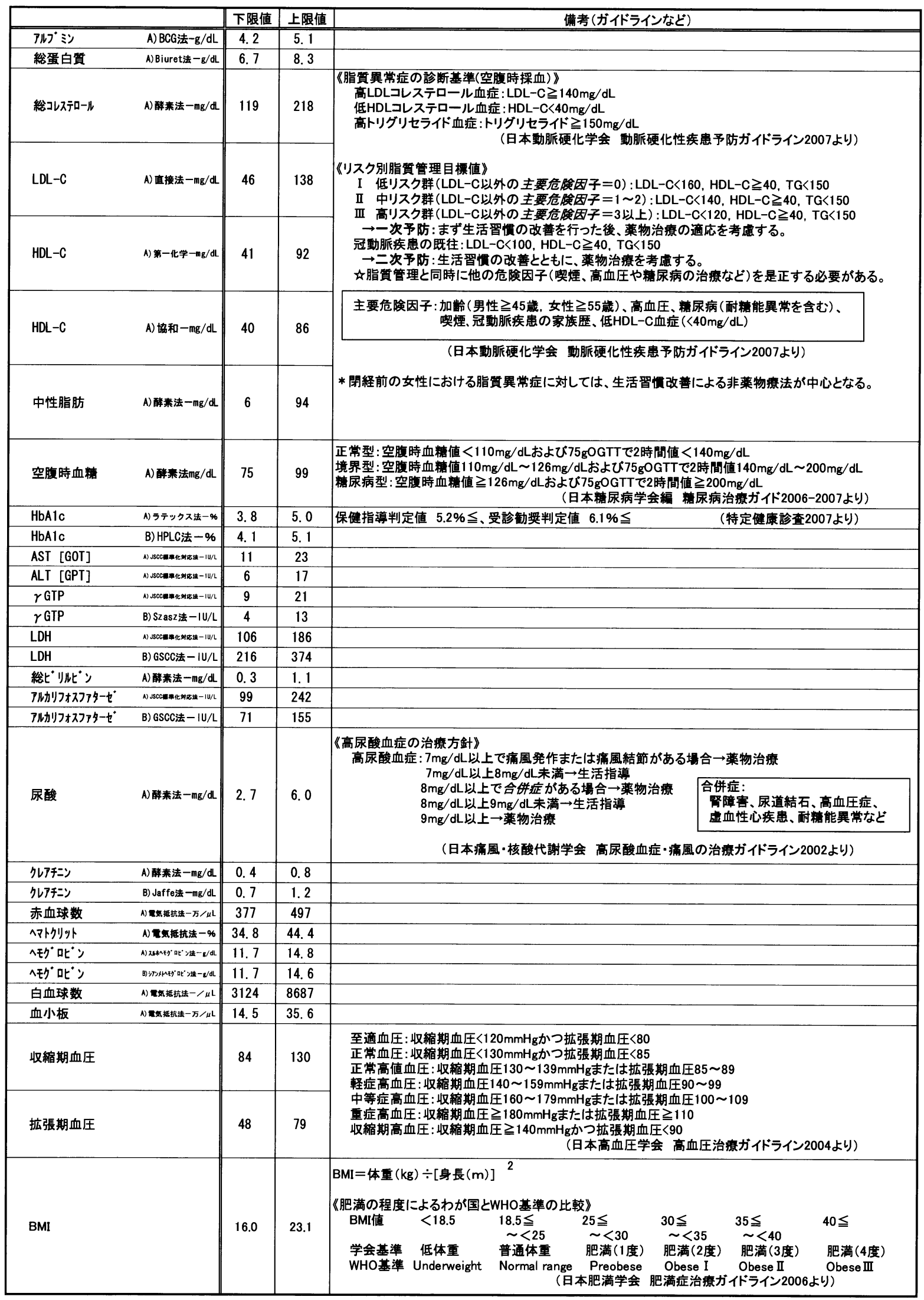




\section{基 準 筑 囲}

女性 25 29歳

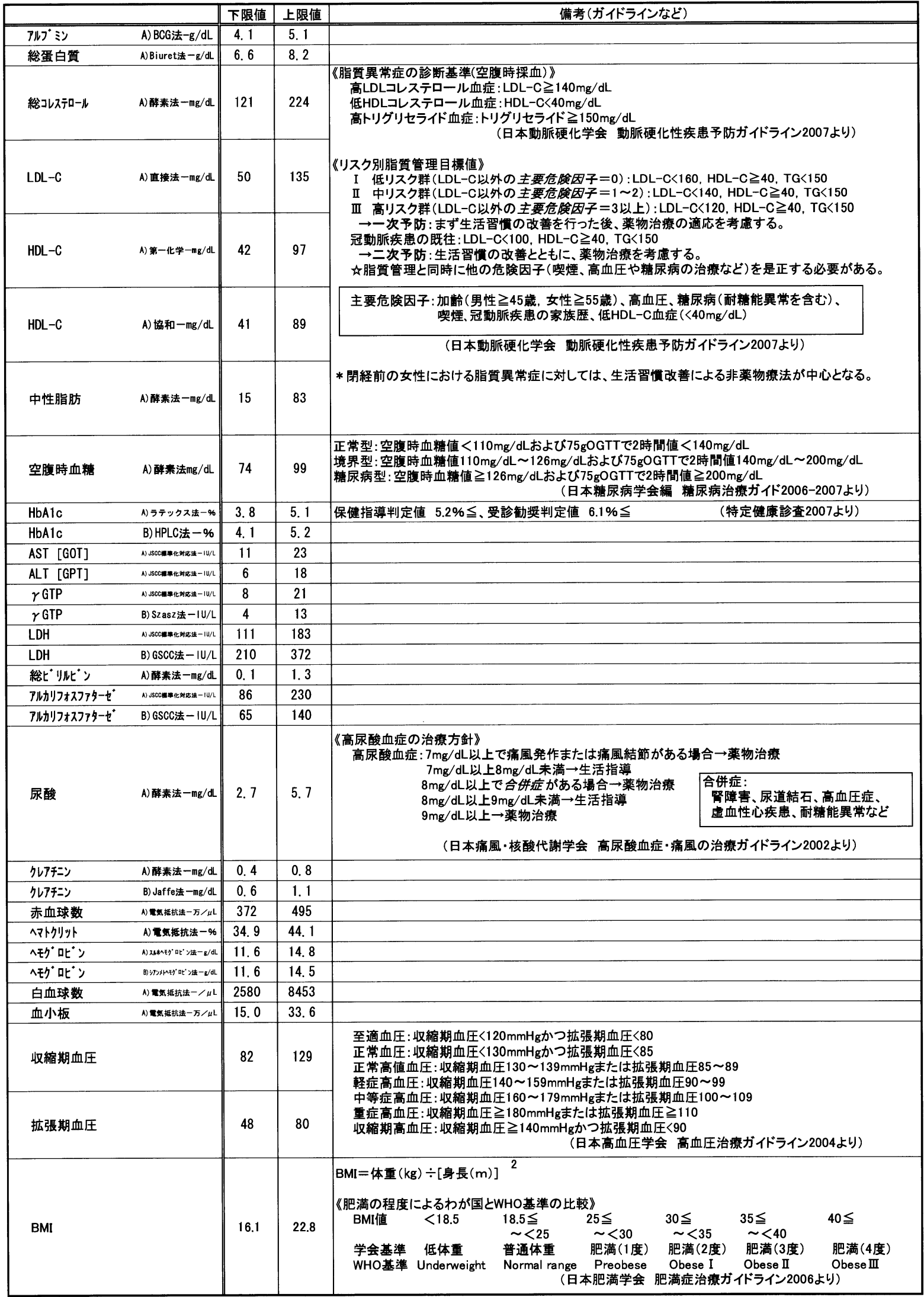


女性 30 34歳

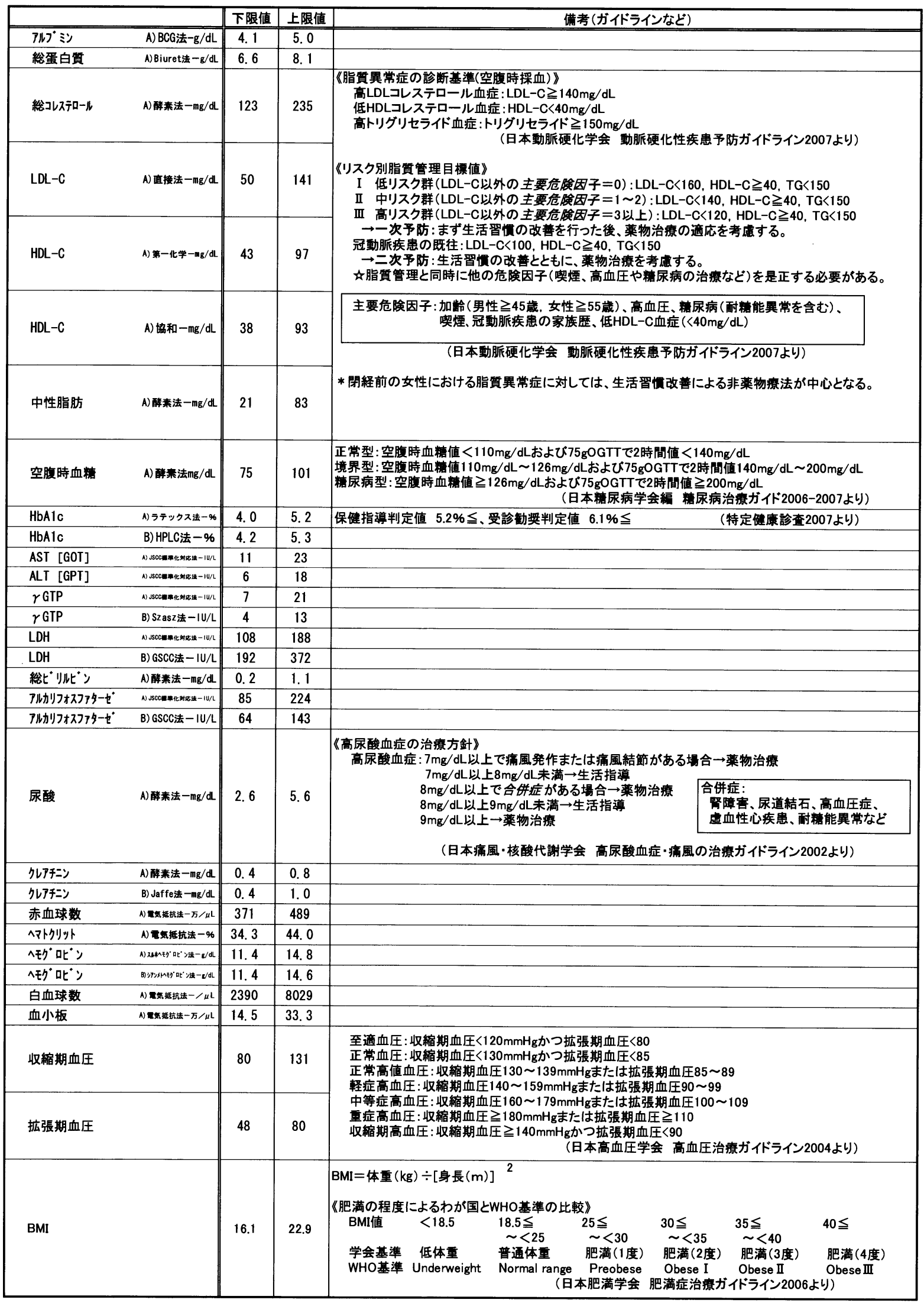


女性 35〜39歳

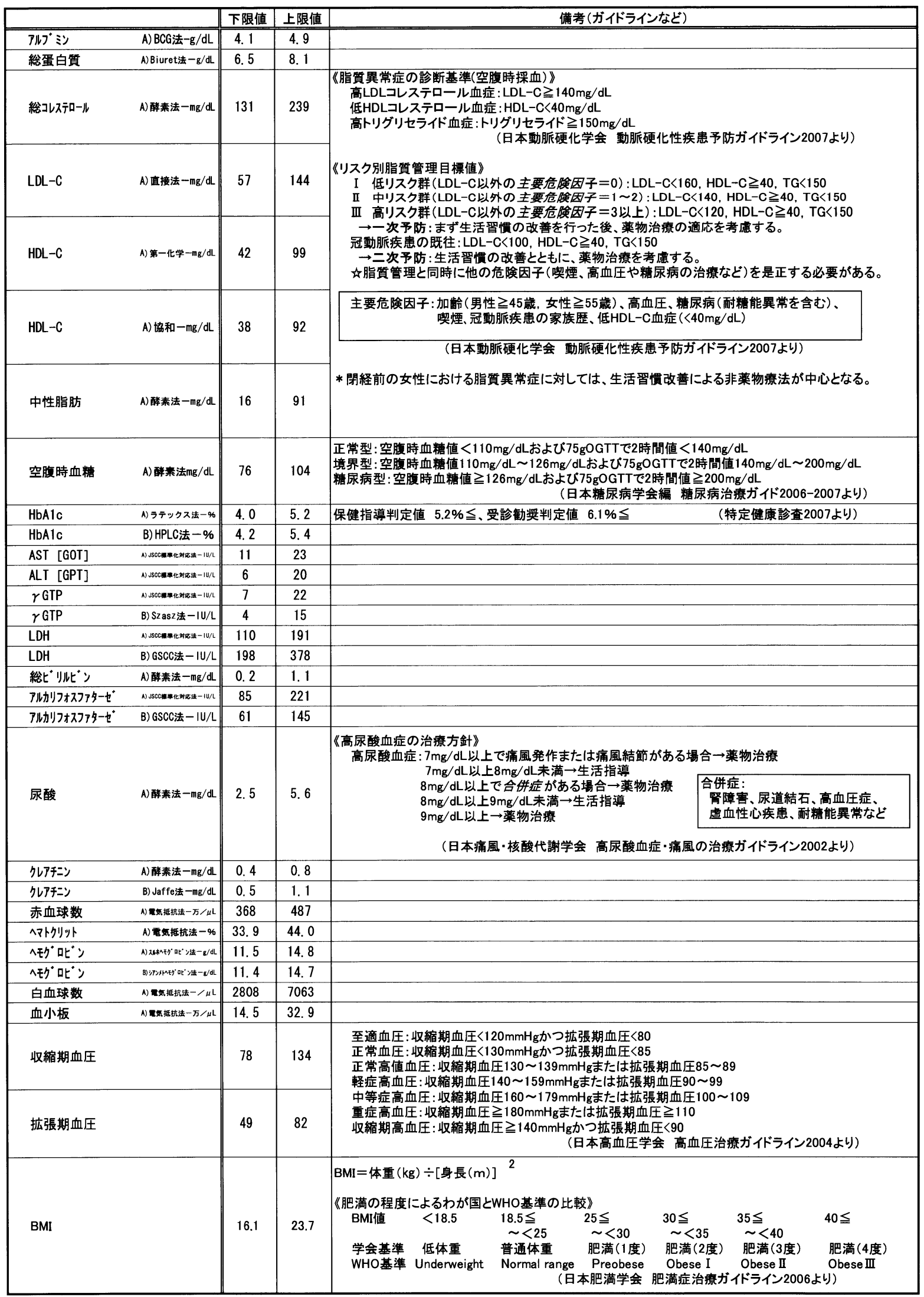


女性 40 44歳

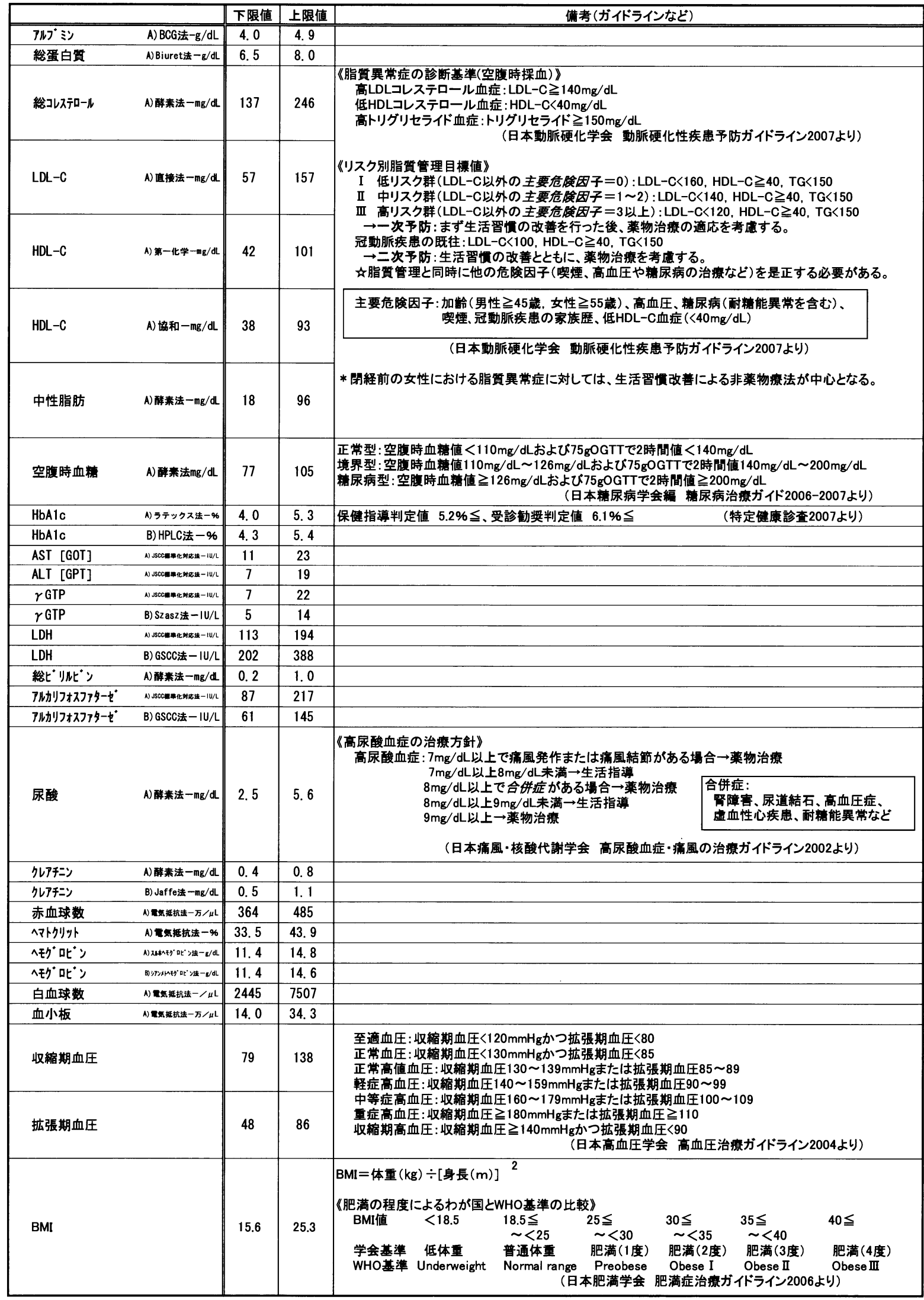


女性 45 49歳

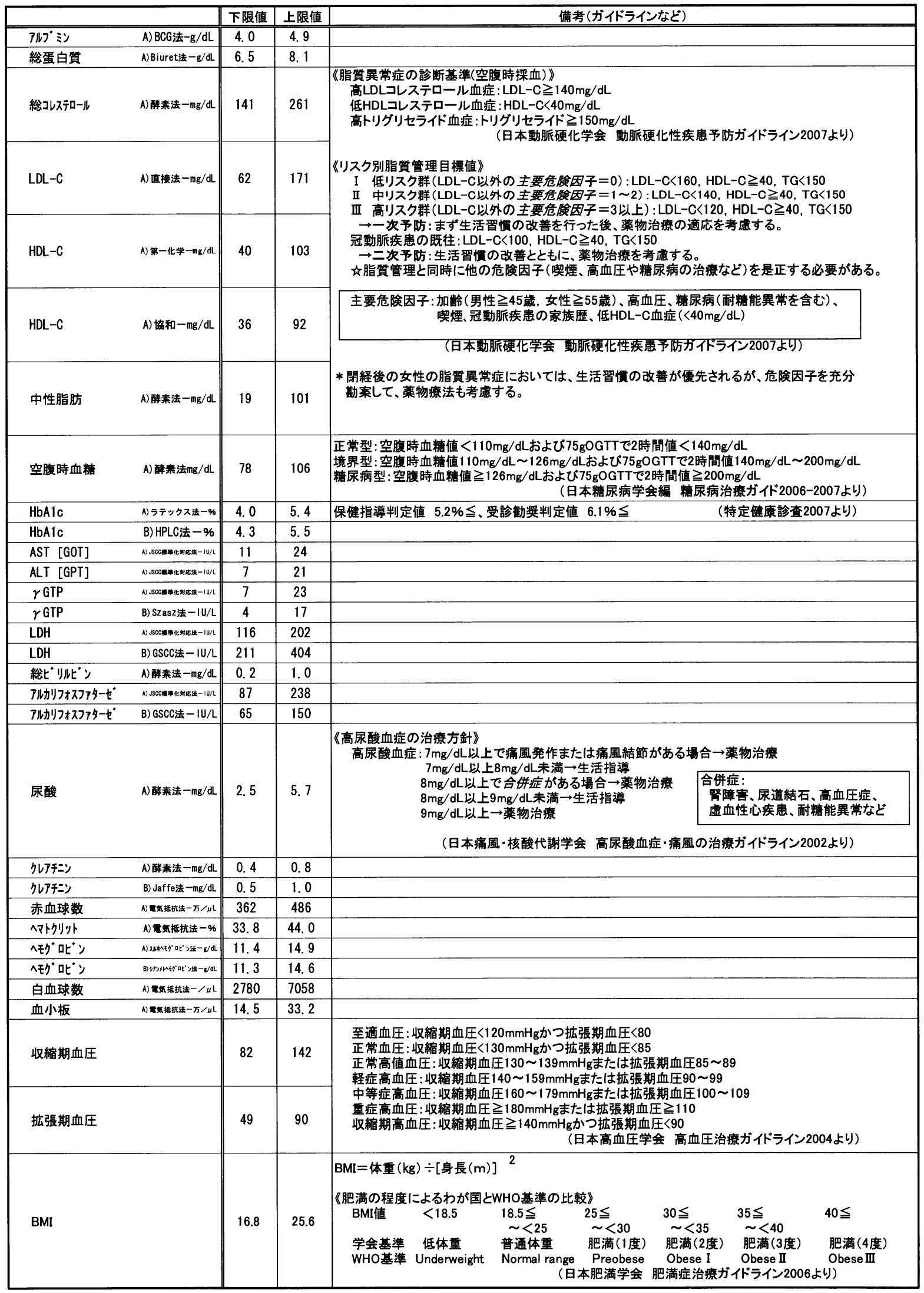


女性 50〜 54歳

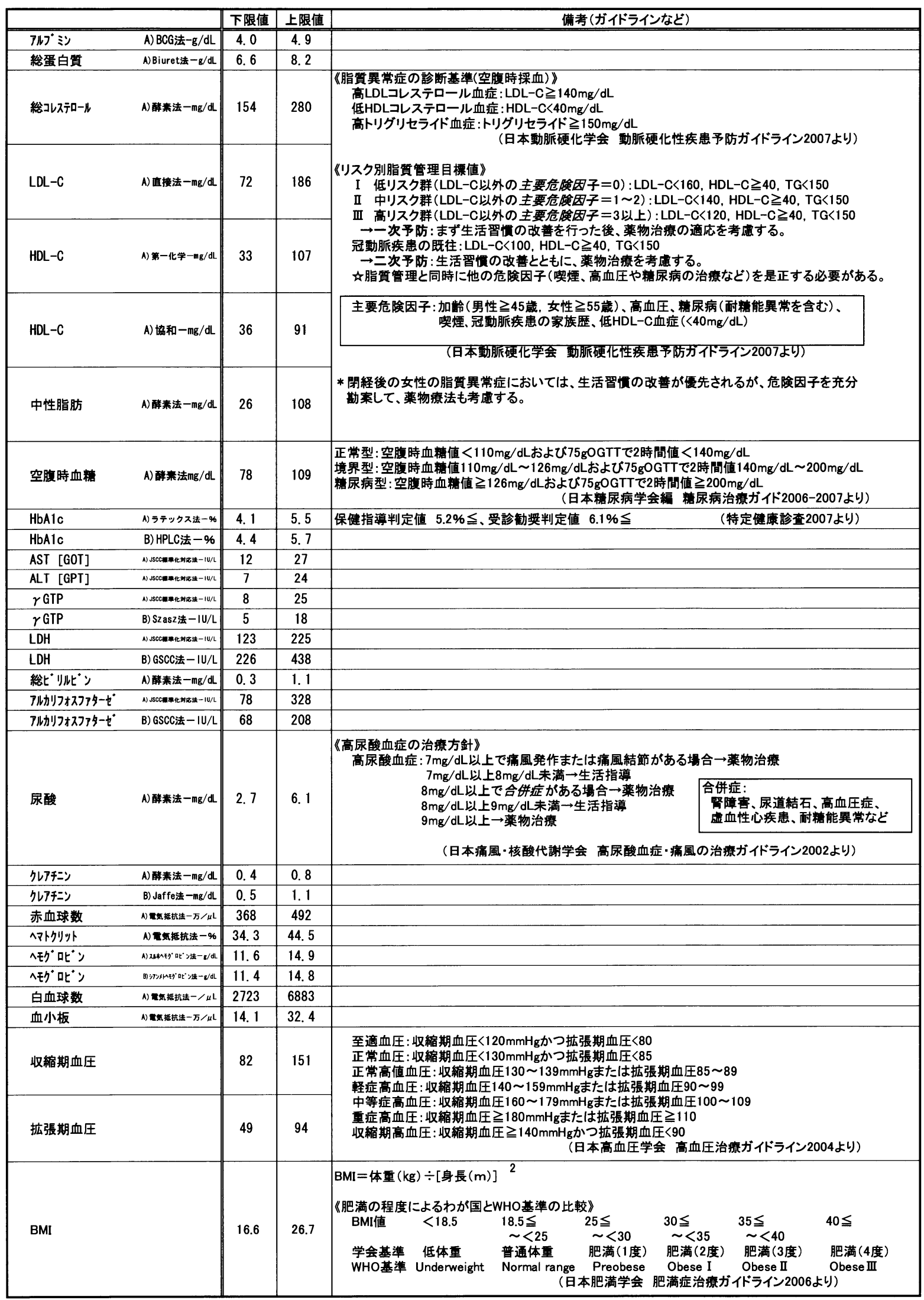


女性 55 59歳

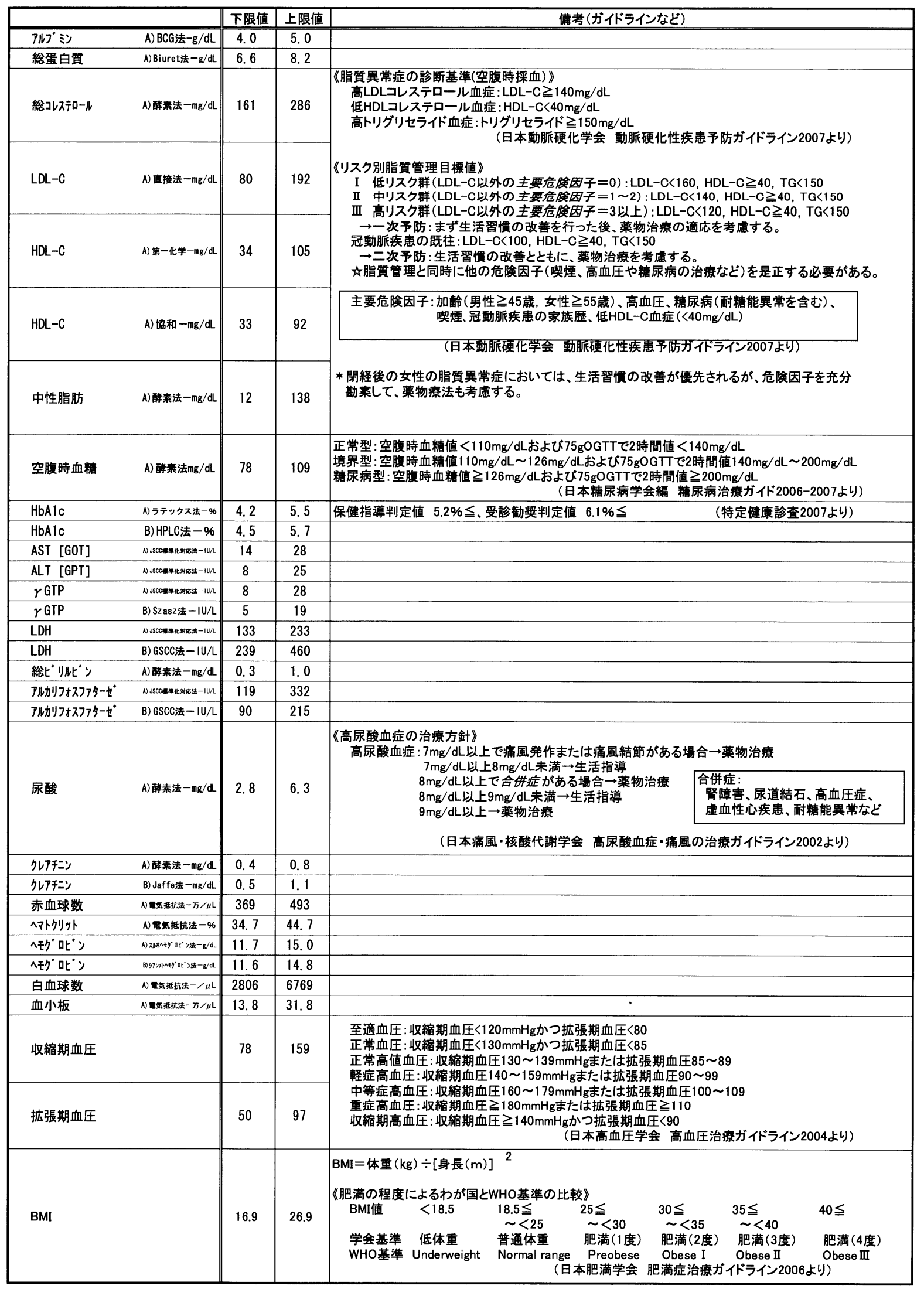


女性 60 64藏

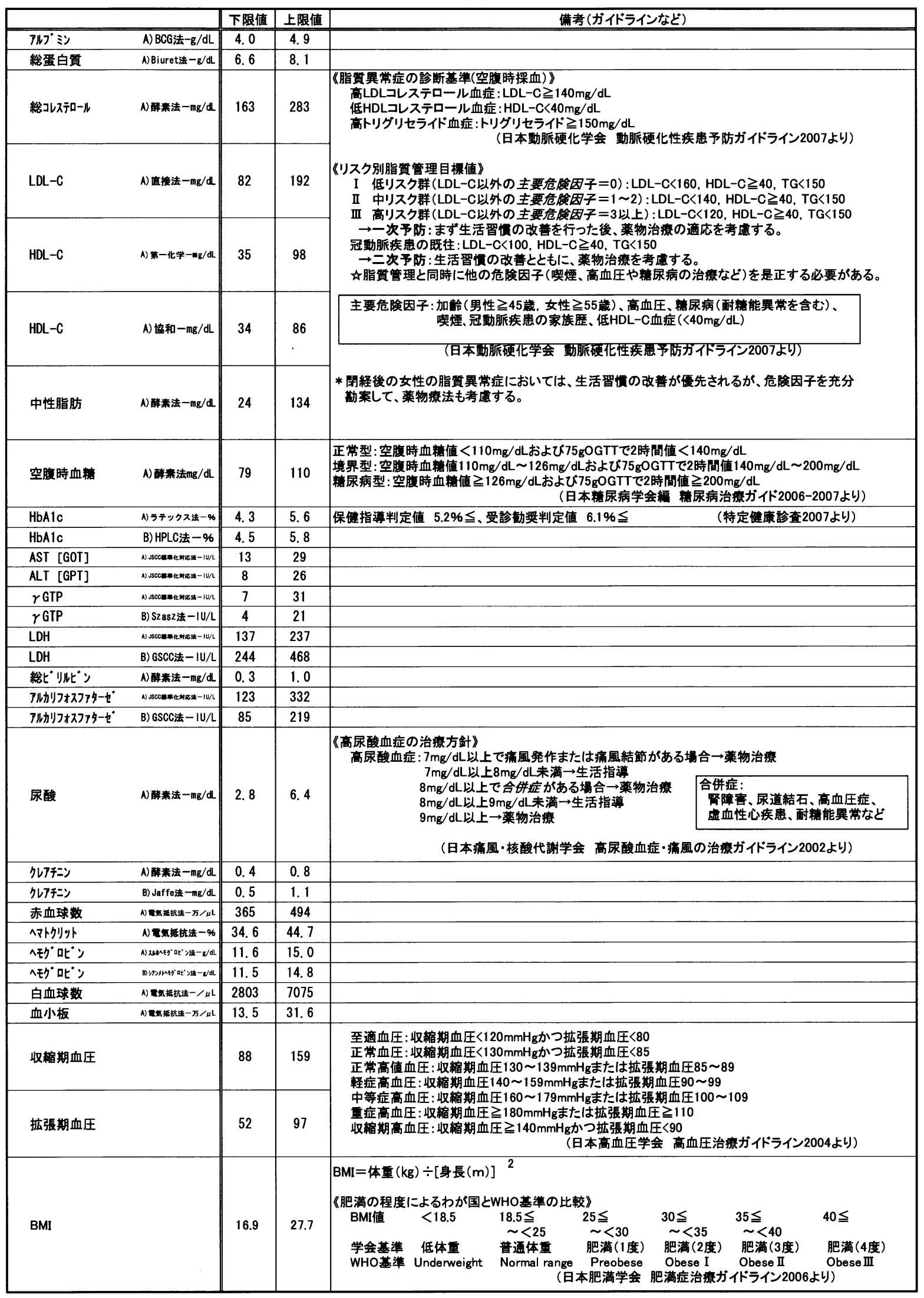




\section{基 準 算 囲}

女性 65 69歳

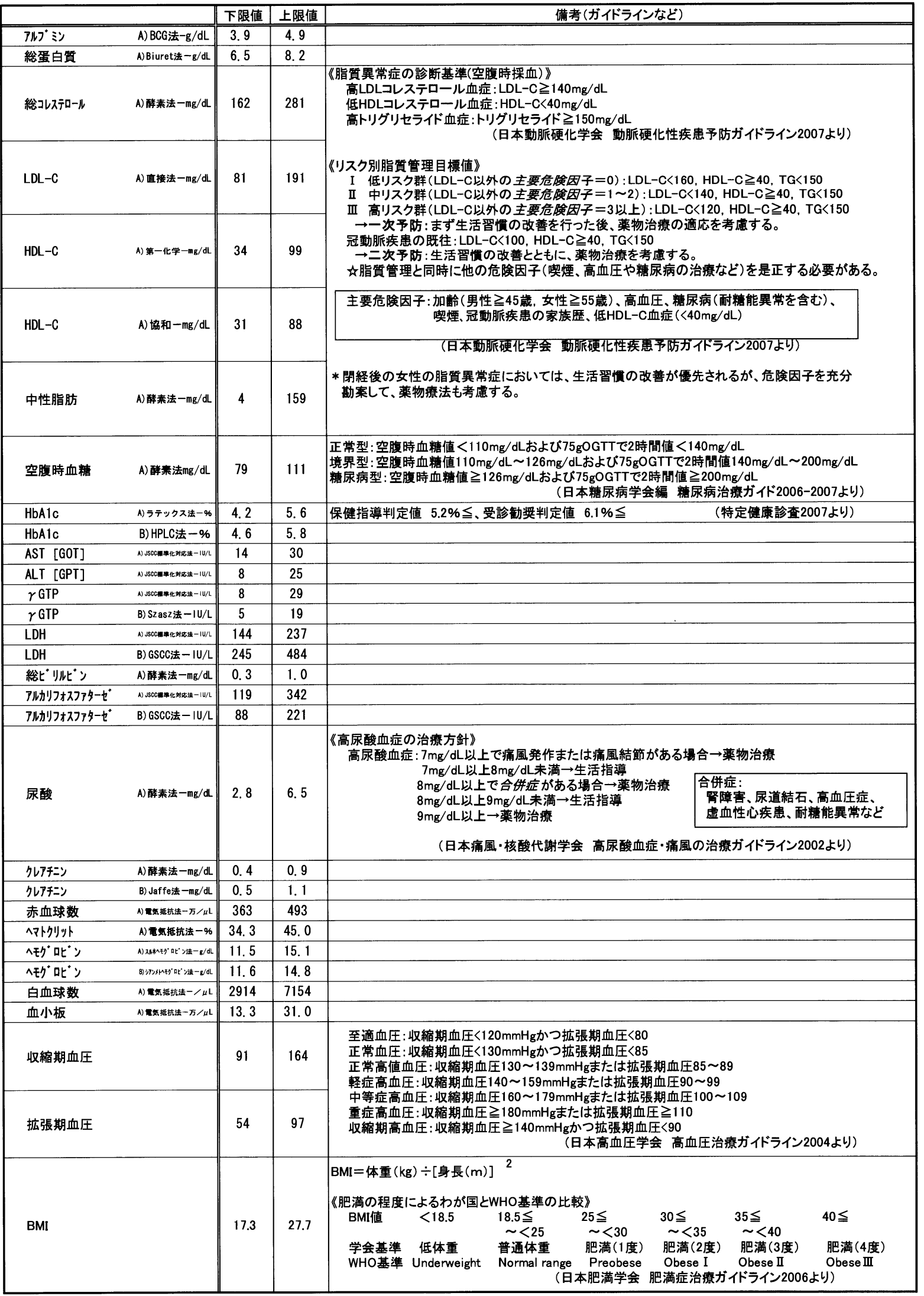




\section{基準 筑 囲}

女性 70 74歳

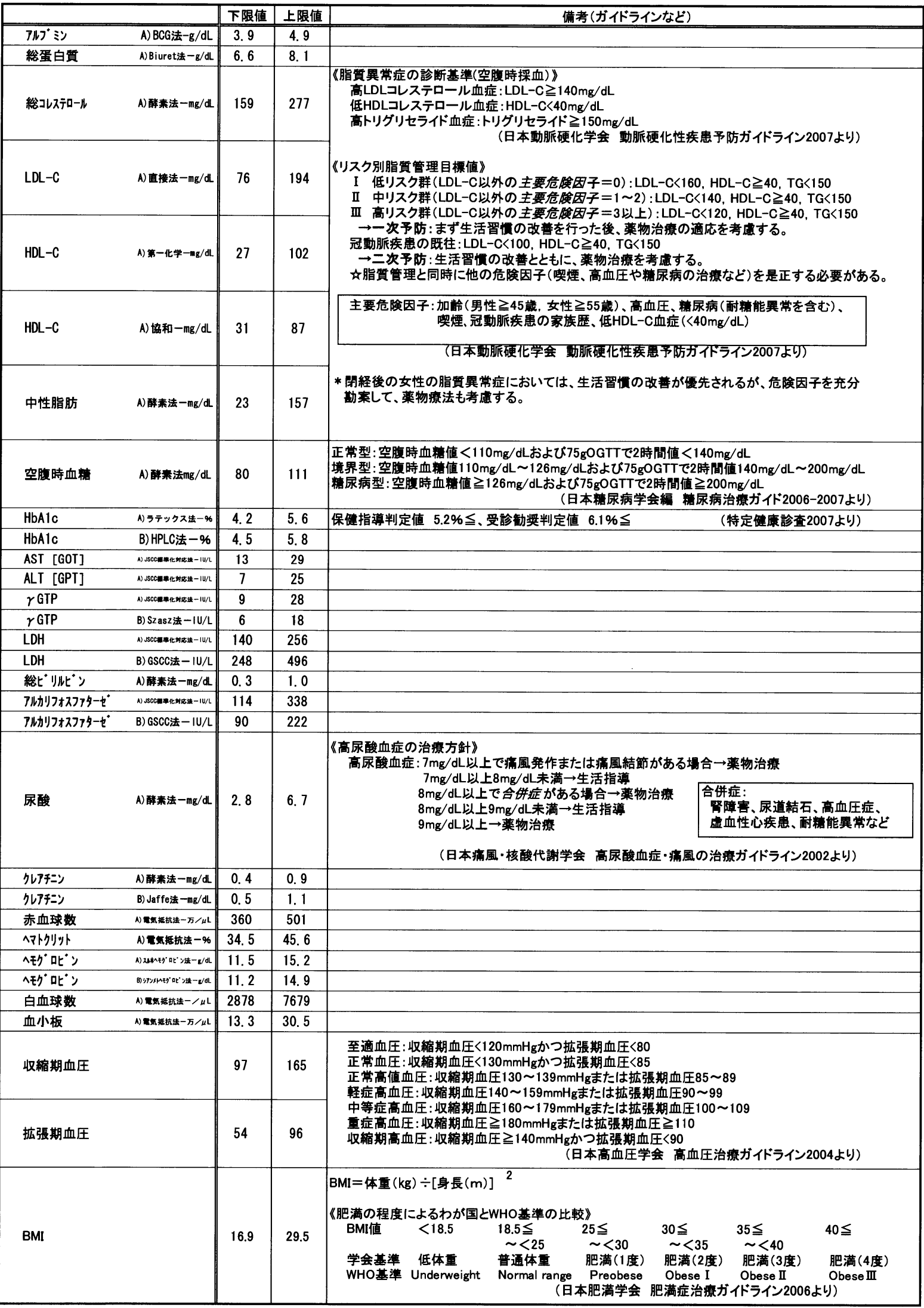




\section{基 準 筑 囲}

女性 75 79歳

\begin{tabular}{|c|c|c|c|c|}
\hline & & 下限値 & 上限値 & 備考(ガイドラインなど) \\
\hline PWV・ シ & A) BCG法-g/dL & \begin{tabular}{c|}
3.8 \\
\end{tabular} & 4.9 & \\
\hline 総蛋白質 & A)Biuret法-g/dL & 6.5 & 8.1 & \\
\hline 総コレステロール & A) 醋素法一的/dL & 150 & 278 & 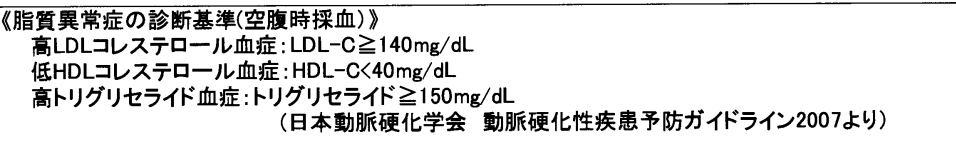 \\
\hline LDL-C & A) 直接法- $\mathrm{mg} / \mathrm{dL}$ & 74 & 194 & \multirow{2}{*}{ 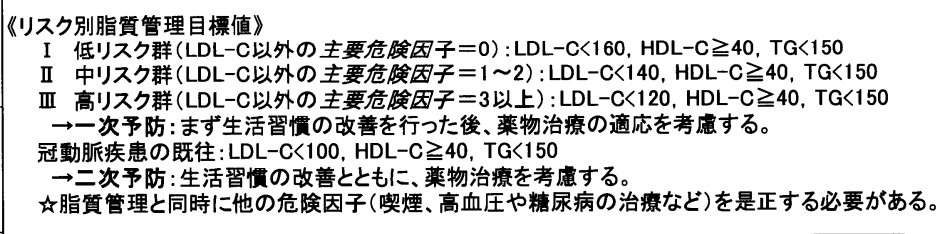 } \\
\hline HDL-C & A) 第-化学 $-\mathrm{mg} / \mathrm{dL}$ & 31 & 101 & \\
\hline HDL-C & A) 協和 $-\mathrm{mg} / \mathrm{dL}$ & 33 & 83 & \multirow{2}{*}{ 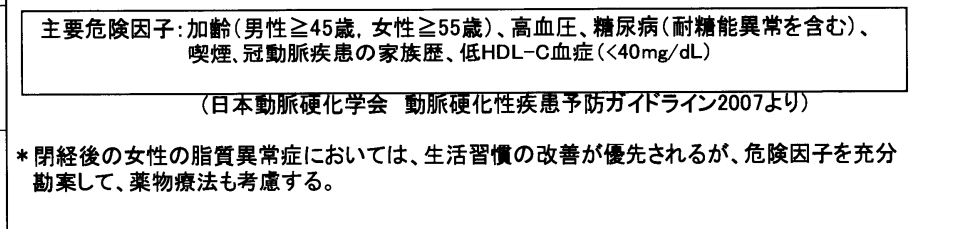 } \\
\hline 中性脂肪 & A)醉素法 $-\mathrm{mg} / \mathrm{dL}$ & 15 & 169 & \\
\hline 空腹時血糖 & A) 䤃秦法mg/dL & 81 & 110 & 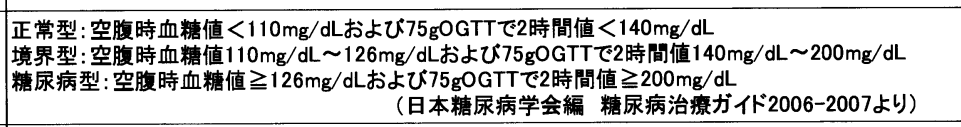 \\
\hline $\mathrm{HbAlc}$ & A)ラテックスス法ー\% & 4.2 & 5.6 & 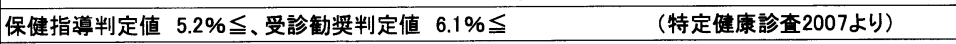 \\
\hline $\mathrm{HbAlc}$ & B) HPLC法-\% & 4.6 & 5.7 & \\
\hline AST [GOT] & 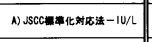 & 13 & 29 & \\
\hline ALT [GPT] & 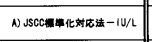 & 7 & 22 & \\
\hline$r$ GTP & 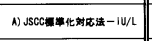 & 9 & 27 & \\
\hline$r$ GTP & B) Szasz法-IU/L & 5 & 18 & \\
\hline $\mathrm{LDH}$ & 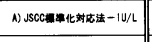 & 133 & 267 & \\
\hline LDH & B) GSCC法-1U/L & 245 & 504 & \\
\hline 総ビリルビン & A)瞵素法 $-\mathrm{mg} / \mathrm{dL}$ & 0.3 & 1.0 & \\
\hline アルかリフォスファターゼ & 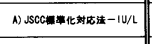 & 119 & 351 & \\
\hline アルかリフォスファターゼ & B) GSCC法-IU/L & 77 & 241 & \\
\hline \multirow[t]{2}{*}{ 尿酸 } & \multirow[t]{2}{*}{ A) 醉素法-mg/dL } & \multirow[t]{2}{*}{3.0} & \multirow[t]{2}{*}{6.8} & \multirow[t]{2}{*}{ 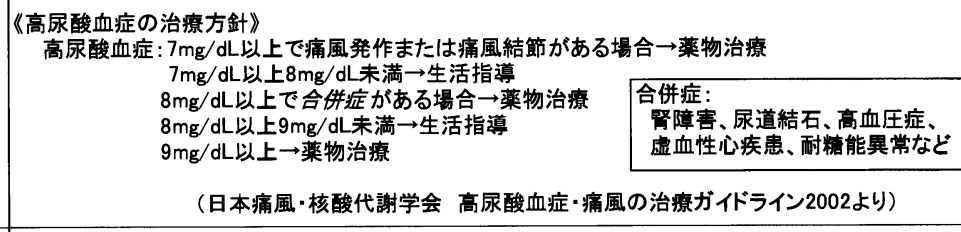 } \\
\hline & & & & \\
\hline クレアチニン & A)醉素法-mg/dL & 0.4 & 0.9 & \\
\hline クレアチニン & B) Jaffe法-mg/dt & 0.5 & 1.2 & \\
\hline 赤血球数 & 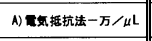 & 356 & 494 & \\
\hline ヘマトクリット & 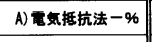 & 33.9 & 45.8 & \\
\hline ^モグロ听ン & 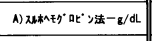 & 11.3 & 15.1 & \\
\hline ヘモグロ听ン & 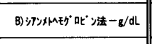 & 11.2 & 14.9 & \\
\hline 白血球数 & 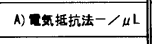 & 2403 & 8239 & \\
\hline 血小板 & 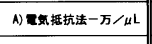 & 12.4 & 30.6 & \\
\hline \multicolumn{2}{|l|}{ 収縮期血圧 } & 100 & 166 & \multirow{2}{*}{ 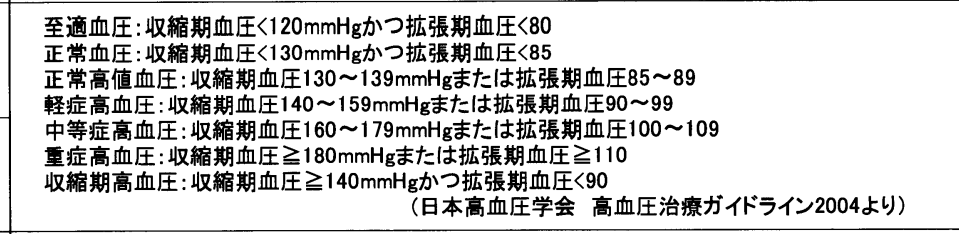 } \\
\hline 拡張期血圧 & & 55 & 95 & \\
\hline \multicolumn{2}{|l|}{ BMI } & 17.1 & 29.7 & 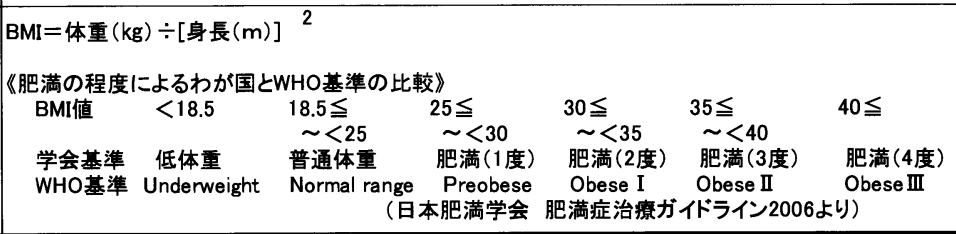 \\
\hline
\end{tabular}

